\title{
Alpine Botany \\ Effect of stand-replacing fires on Mediterranean plant species in their marginal alpine range \\ --Manuscript Draft--
}

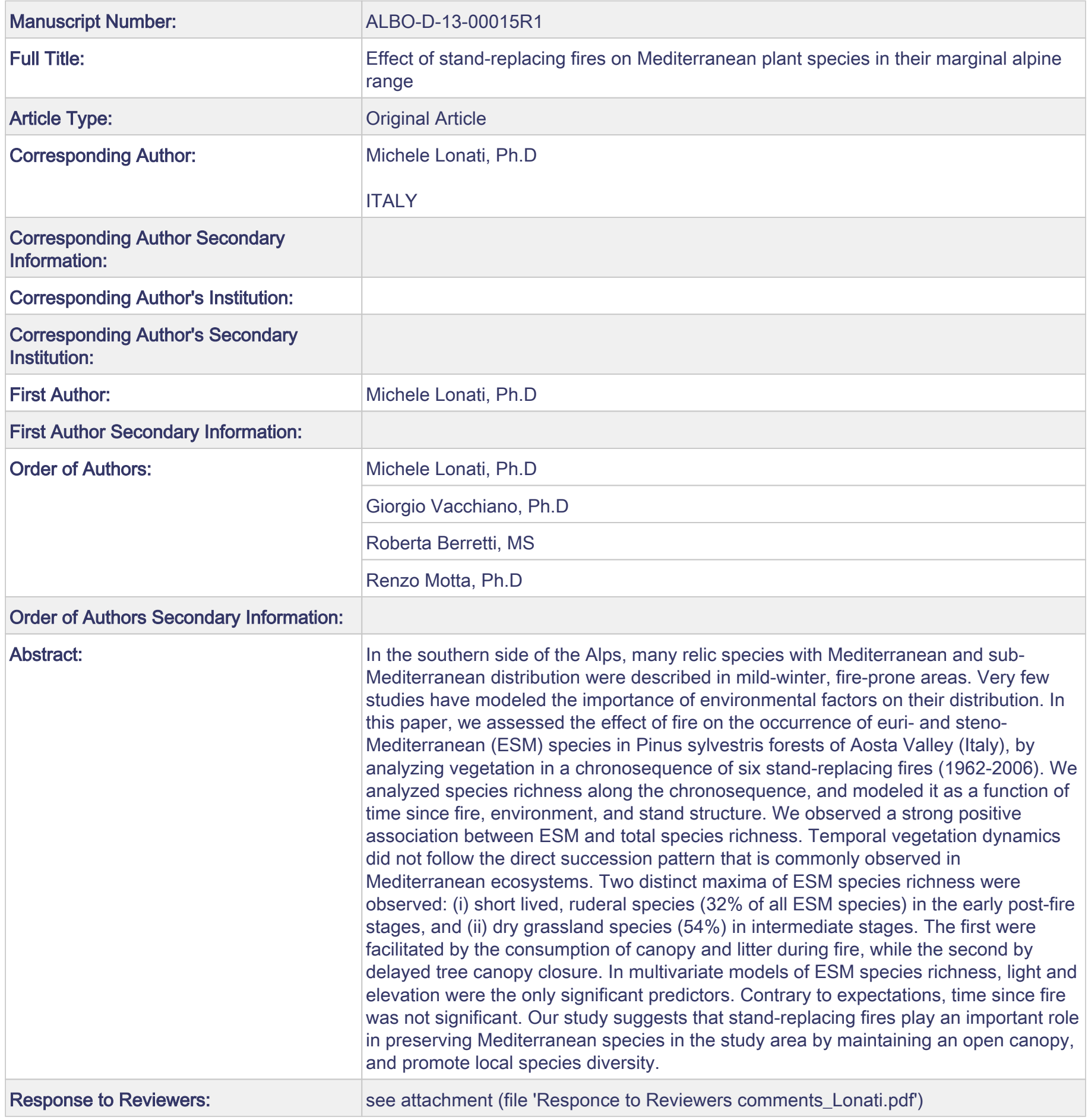


Ref.: Ms. No. ALBO-D-13-00015

Effect of stand-replacing fires on Mediterranean plant species in their marginal alpine range

Alpine Botany

Dear Jürg Stöcklin,

We reviewed the paper and we provided the revision of your manuscript according to your critical remarks. The reviewers' comments can be found in this document. For each, we added a list of change points.

Sincerely,

Michele Lonati and co-Authors

Answers to Reviewers' comments

\section{Comments of Referee 1}

Reviewer \#1: General impression

The $\mathrm{ms}$ is well written in respect to style and language. I found only few things and I have the impression the $\mathrm{ms}$ is already copy-edited. Statistical analyses are simple and results easy to understand. I have two major concerns:

1) Chronosequence: It is well explained why the authors talk of a chronosequence. Most importantly, the burns are in close proximity, which makes the same species pool quite feasible and the idea of a chronosequence obvious. However, the burns cannot be viewed as one study site where species compositions follow a strict succession series like in a monitoring study site. This should be kept in mind if drawing graphs (scatter graphs instead of line graphs) or discussing communities classified into four time classes. Space for time is a too rough approach here; consider that there are only $\mathbf{3 0}$ relevés!

2) Essence of the study: In total 28 species Mediterranean plant species (ESM; most of them with a wider distribution, i.e. euri-med) were found in 6 forest burns; the number of these species was smaller on old areas, presumably because of advanced succession. Not surprisingly, the ESM species were more frequent at low elevations and in places with much light.

In summary, I consider the results poor; but given the fact that there is almost no information on vegetation following forest fires (only grey literature in the Valais, but at least recent), the information is new.

Authors' comments: see details, that address all the general impressions

\section{Details}

1) Page 2, line 4: according to the following text: euri- and steno-Mediterranean

Authors' comments: we modified the text according to your observation.

Old version:

'In this paper, we assessed the effect of fire on the occurrence of steno- and euri-Mediterranean (ESM) species in Pinus sylvestris forests ....'

New version:

'In this paper, we assessed the effect of fire on the occurrence of euri- and steno- Mediterranean (ESM) species in Pinus sylvestris forests...'

2) Page 4, line 15: Give a reference for the GIS-software, even if it is open-source.

Authors' comments: we added the reference of the software (Quantum GIS 1.8).

Old version:

'Selected fire perimeters were georeferenced in a GIS.'

New version:

'Selected fire perimeters were georeferenced using Quantum GIS 1.8 (Quantum GIS Development Team, 2012).'

Added in the References:

Quantum Gis Development Team (2012). Quantum GIS Geographic Information System. Open Source Geospatial Foundation Project (http://qgis.osgeo.org)

3) Page 4, line 28: two out of six, not five out of six; the sentence give a fully different picture than what is listed in Table 1. I see three larger burns (22 ha, 47 ha and $168 \mathrm{ha}$ ) and three quite small fires (2 ha, 5 ha, 5 ha)

Authors' comments: according with your observation, we used data from the 'Regional plan for forecasting, preventing and countering wildfires' (Bovio et al. 2005; quoted in the text) to define 'small fire' (fires smaller than 8 ha).

Old version: 
'Area burned by crown fire was 41 ha on average, and $<50$ ha in five out of six sites.' New version:

'Area burned by crown fire was 41 ha on average, and $<8$ ha in three out of six sites.'

\begin{abstract}
4) Page 5, line 14: What if somebody is not familiar with Pignatti's chorotypes? Explain the meaning of euri- and steno-Mediterranean.

Authors' comments: we added the definition of euri- and steno-Mediterranean in the text.

Added sentence (In yellow):

'The recorded species were classified according to their biogeographic distribution (chorotypes) following Pignatti (1982). For each plot, we computed the total number of euri- and steno-Mediterranean (ESM) species. StenoMediterranean species show a distribution range strictly related to the Mediterranean basin, while euri-Mediterranean species show a larger distribution range, extending north and east of Mediterranean coastal areas (Pignatti 1982). The phytosociological optimum was associated to each species according to Aeschimann et al. (2004).'
\end{abstract}

5) Page 5, line 25: Just a question: why U for 'soil moisture'?

Authors' comments: we agree with your comment. In the original work Landolt codified 'soil moisture' with the letter ' $F$ ' (see Landolt, 1977). We replaced ' $U$ ' con ' $F$ ' in all the paper.

6) Page 7, line 10: This is the earliest stage, i.e. 4th year, or better $<5$ years. However, to my impression, there is too little data to make generalisation.

Authors' comments: according to your impression (too little data to make generalisation) we rewrote the results (and the phytosociological description) avoiding generalisation, e.g. we replaced 'stage' with 'site'. We would maintain the phytosociological description, because Figure 3 show a clear separation of the species between the first site (annual early seral species) and the others. We also replaced ' 5 years' with ' 4 years' because now we describe the floristic composition of the 'younger site'.

The term 'stage' is still being used in the discussion, because a little generalisation was necessary to respond to the aims of the work.

Old version:

'..... Total shrub cover (including saplings) increased to $30-40 \%$ in intermediate successional stages, and decreased from 15 years after fire, when pine saplings exceeded $5 \mathrm{~m}$ height as shown by the contemporary increase in tree cover (Table 1). A moderate to high herbaceous cover was registered at all stages, without a clear trend along the chronosequence.

Total species richness ( $\alpha$-diversity) was high in the early post-fire stages, but significantly decreased in the 48 years-old site (24 species) (Fig. 1). Similarly, ESM species richness was significantly higher in the first (4 years-old) and intermediate (15-35 years-old) stages of the chronosequence, while in the oldest site they almost disappeared. Shannon index decreased significantly along the chronosequence, with very low values (less than 3 ) in the 48 years-old stand, when Scots pine achieved dominance in the tree layer.

A positive and significant correlation was found at the plot scale between ESM and total species richness (Fig. 2a). A similar relationship was found between ESM species richness and the Shannon index (Fig. 2b), although only $25 \%$ of the variability of ESM species richness was explained.

DCA ordination evidenced a clear separation between the different stages of the succession (Fig. 3a). The first two axes explained $18.4 \%$ of total variance (eigenvalues $=0.480$ and 0.230 , respectively).

Axis 1 helped discriminate the early (4 years-old), intermediate ( 5 to 35 years-old) and late (48 years-old) successional stages. Axis 2 helped separate the first intermediate (5 to 7 years-old) from the second intermediate stages (15 to 35 years-old). The species plot evidenced rather clear groups of species (dotted lines in Fig. 3b).

From a phytosociological point of view, the chronosequence can be described by the following:

I - the initial stage (5 years-old) was dominated by therophytic, early-seral species belonging to the classes KoelerioCorynephoretea (e.g., Minuartia fastigiata, Petrorhagia prolifera), Thero-Brachypodietea (e.g., Linaria simplex, Medicago minima), and Stellarietea mediae (e.g., Ajuga chamaepitys, Conyza canadensis). Also important was the presence of ruderal nitrophilous species from the classes Agropyretea intermedii-repentis (e.g., Convolvulus arvensis, Tragopogon dubius) and Artemisietea vulgaris (e.g., Lactuca serriola, Daucus carota). Only a few of the therophytic species persisted in the intermediate stages (Appendix 1 in the Supplementary Material);

II - in the first intermediate stages (5 to 7 years-old), ruderal species belonging to the class Artemisietea vulgaris (e.g., Carduus nutans, Erigeron annuus, Senecio inaequidens) decreased, while species from meso-xerophile shrub and fringe communities (Crataego-Prunetea and Trifolio-Geranietea sanguinei) and dry grasslands (Festuco-Brometea) increased. This last group accounted for a total of 32 species, showing also many characteristic species of the class or related syntaxa;

III- in the second intermediate stages (15 to 35 years-old), species from the Festuco-Brometea decreased to 17 . We observed an increase of species belonging to the class Crataego-Prunetea (e.g., Prunus spinosa, Prunus mahaleb, Juniperus communis), Querco-Fagetea s.l. (broadleaved forests: e.g., Quercus pubescens, Prunus aviun), and Pyrolo-Pinetea (Scots pine forests: e.g., Saponaria ocymoides, Arctostaphylos uva-ursi and P. sylvestris itself); 
IV - in the final stage (48 years-old) species belonging to the class Festuco-Brometea almost disappeared. We observed many species from the class Querco-Fagetea s.l. (e.g., Fraxinus excelsior, Sorbus aria, Lathyrus montanus) and some from boreal, acidophilous woody communities (Vaccinio-Piceetea excelsae: e.g., Picea excelsa, Melampyrum sylvaticum, Vaccinium myrtillus).

Time since fire was positively correlated to both the first and the second DCA axis (Pearson's $\mathrm{R}=0.61, \mathrm{p}<0.001$, and $\mathrm{R}=0.56, \mathrm{p}<0.001$, respectively). ESM species were abundant in the early and intermediate stages of the succession (Fig. 3b). A significant, negative correlation $(\mathrm{R}=-0.76)$ was detected between DCA1 and the number of ESM species (Fig. 4a). DCA2 did not show any significant correlation with ESM species richness (Fig. 4b).

\section{New version:}

'..... Total shrub cover (including saplings) increased up to $40 \%$ in the first 7 years after fire and decreased from 15 years after fire, when pine saplings exceeded $5 \mathrm{~m}$ height as shown by the contemporary increase in tree cover (Table 1). A moderate to high herbaceous cover was registered at all stages, without a clear trend along the chronosequence.

Total species richness ( $\alpha$-diversity) was high in the younger post-fire sites, but significantly decreased in the 48 yearsold site (24 species) (Fig. 1). Similarly, ESM species richness was significantly higher in the first (4 years-old) and intermediate (15-35 years-old) stages of the chronosequence, while in the oldest site they almost disappeared. Shannon index decreased significantly along the chronosequence, with very low values (less than 3 ) in the 48 years-old stand, when Scots pine achieved dominance in the tree layer.

A positive and significant correlation was found at the plot scale between ESM and total species richness (Fig. 2a). A similar relationship was found between ESM species richness and the Shannon index (Fig. 2b), although only $25 \%$ of the variability of ESM species richness was explained.

DCA ordination evidenced a clear separation between the different sites of the succession (Fig. 3a). The first two axes explained $18.4 \%$ of total variance (eigenvalues $=0.480$ and 0.230 , respectively).

Axis 1 helped discriminate the youngest (4 years-old), intermediate (5 to 35 years-old) and oldest (48 years-old) sites. Axis 2 helped separate the first intermediate ( 5 to 7 years-old) from the second intermediate stages (15 to 35 -years-old). The species plot evidenced rather clear groups of species (dotted lines in Fig. 3b).

From a phytosociological point of view, a chronosequence can be described by the following:

I - the youngest site (4 years-old) was dominated by therophytic, early-seral species belonging to the classes KoelerioCorynephoretea (e.g., Minuartia fastigiata, Petrorhagia prolifera), Thero-Brachypodietea (e.g., Linaria simplex, Medicago minima), and Stellarietea mediae (e.g., Ajuga chamaepitys, Conyza canadensis). Also important was the presence of ruderal nitrophilous species from the classes Agropyretea intermedii-repentis (e.g., Convolvulus arvensis, Tragopogon dubius) and Artemisietea vulgaris (e.g., Lactuca serriola, Daucus carota). Only a few of the therophytic species persisted in the intermediate sites (Appendix 1 in the Supplementary Material);

II - in the first intermediate sites ( 5 to 7 years-old), ruderal species belonging to the class Artemisietea vulgaris (e.g., Carduus nutans, Erigeron annuus, Senecio inaequidens) decreased, while species from meso-xerophile shrub and fringe communities (Crataego-Prunetea and Trifolio-Geranietea sanguinei) and dry grasslands (Festuco-Brometea) increased. This last group accounted for a total of 32 species, showing also many characteristic species of the class or related syntaxa;

III- in the second intermediate sites (15 to 35 years-old), species from the Festuco-Brometea decreased to 17. We observed an increase of species belonging to the class Crataego-Prunetea (e.g., Prunus spinosa, Prunus mahaleb, Juniperus communis), Querco-Fagetea s.l. (broadleaved forests: e.g., Quercus pubescens, Prunus aviun), and Pyrolo-Pinetea (Scots pine forests: e.g., Saponaria ocymoides, Arctostaphylos uva-ursi and P. sylvestris itself);

IV - in the oldest site (48 years-old) species belonging to the class Festuco-Brometea almost disappeared. We observed many species from the class Querco-Fagetea s.l. (e.g., Fraxinus excelsior, Sorbus aria, Lathyrus montanus) and some from boreal, acidophilous woody communities (Vaccinio-Piceetea excelsae: e.g., Picea excelsa, Melampyrum sylvaticum, Vaccinium myrtillus).

Time since fire was positively correlated to both the first and the second DCA axis (Pearson's $\mathrm{R}=0.61, \mathrm{p}<0.001$, and $\mathrm{R}=0.56, \mathrm{p}<0.001$, respectively). ESM species were abundant in the youngest and intermediate sites (Fig. $3 \mathrm{~b}) . \mathrm{A}$ significant, negative correlation $(\mathrm{R}=-0.76)$ was detected between DCA1 and the number of ESM species (Fig. 4a). DCA2 did not show any significant correlation with ESM species richness (Fig. 4b). .....'

7) Page 9, lines 19-20: This is a rather surprising statement since equilibrium has not been touched in the preceding text. What is in this context equilibrium after fire? A state of unchanged species abundances, i.e. constant plant community? This can only be reached if trees have formed a darkenough stand or if grass species have formed a stand in which trees are hindered to germinate. But all this is not so easy to derive from 6 different burns. And in addition, there is no deeper consideration of this equilibrium thing.

Authors' comments: we agree with your comment and we decided to remove the second sentence Old version:

'Total species diversity (Shannon index) was less predictable, probably due to the influence of local environmental variables on species cover. In addition, species abundances following disturbance may not reach equilibrium (Wilson 2012); this could probably affect Shannon diversity index, which is computed on abundance data.' 


\section{New version:}

'Total species diversity (Shannon index) was less informative, probably due to the influence of local environmental variables on species cover.'

\section{8) Page 9/10: Conclusion: Essentially, $50 \%$ of the conclusion is not directly related to the results found, i.e. it seem to me blown up.}

Authors' comments: we reduced (of about 50\%) the conclusion, limiting comments to the data directly related to the results.

Old version:

'Light conditions and elevation were the most important factors affecting the richness of Mediterranean species in the study area. The late spread of perennial grassland species after fire, probably limited by seed dispersal distance, resulted in a significant but weak dependence of Mediterranean species richness on time since fire.

Soil water limitations in dry, inner-alpine valleys result in a delayed tree canopy closure, and have a positive effect on the maintenance of heliophilous Mediterranean species in the intermediate stages of post-fire succession. Additionally, salvage logging, a management practice commonly applied in Aosta Valley after stand-replacing fires, may significantly delay Scots pine regeneration (Beghin et al. 2010). In unsalvaged areas, deadwood provides safe sites for the establishment of Scots pine regeneration, mitigating insolation and drought (Marzano et al. 2013), but is probably associated to less favorable conditions for Mediterranean species.

Our study suggests that stand-replacing crown fires play an important role in preserving Mediterranean species and promote local species diversity in the study area. Fires create (i) conditions favorable to the development of short-lived Mediterranean species in the first years after disturbance, and (ii) a spatio-temporal mosaic of dry grassland, shrub, and tree patches, characterized by many perennial Mediterranean grassland species. In the light of climate change scenarios, an increase in fire frequency and severity is expected (Zumbrunnen et al. 2009, 2011), along with upward migration of several plant species (Theurillat and Guisan 2001; Fyllas and Troumbis 2009). In dry, inner-alpine valleys, prolonged drought periods and increasing size of stand-replacing fires will aggravate bottlenecks to tree recruitment in Scots pine forests, and induce a shift to non-forest vegetation (Moser et al. 2010; Rigling et al. 2012). These processes are feared to negatively affect plant distribution and diversity (Beaumont et al. 2011). However, in this context, thermophilous Mediterranean species, occurring preferentially on warm and dry sites, should benefit from climate change, conserving their initial habitats and/or expanding to new suitable areas.'

\section{New version:}

'Our study suggests that stand-replacing crown fires play an important role in preserving Mediterranean species and promote local species diversity in the study area. Fires create (i) conditions favorable to the development of short-lived Mediterranean species in the first years after disturbance, and (ii) a spatio-temporal mosaic of dry grassland, shrub, and tree patches, characterized by many perennial Mediterranean grassland species.

Light conditions and elevation were the most important factors affecting the richness of Mediterranean species in the study area. Moreover, soil water limitations in dry, inner-alpine valleys result in a delayed tree canopy closure, and have a positive effect on the maintenance of heliophilous Mediterranean species in the intermediate stages of post-fire succession.

In the light of climate change scenarios, an increase in fire frequency and severity is expected (Zumbrunnen et al. 2009, 2011), promoting the conservation of the Mediterranean species across the Alps.'

9) Fig. 1: Since the sequence is not a true chronosequence (look at the bimodal curve, which is counter-intuitive and cannot be explained in a true chronosequence), the time-points must not be related by a line. A fitted curve (regression; linear or quadratic term) is more adequate. In Fig. 3, there is evidence that the 6 burns distinctly differ from each other.

Authors' comments: we removed the line in Figure 1. However, we decided not to draw a fitted curve, because the aim of Figure 1 is the comparison of means (Anova and Post hoc tests) and not the description of a regression line. If you agree, we would like to remove the scale of the 'Years after fire' axis, in order to highlight the differences between means rather than the trend along time. 
Original version of Figure1:

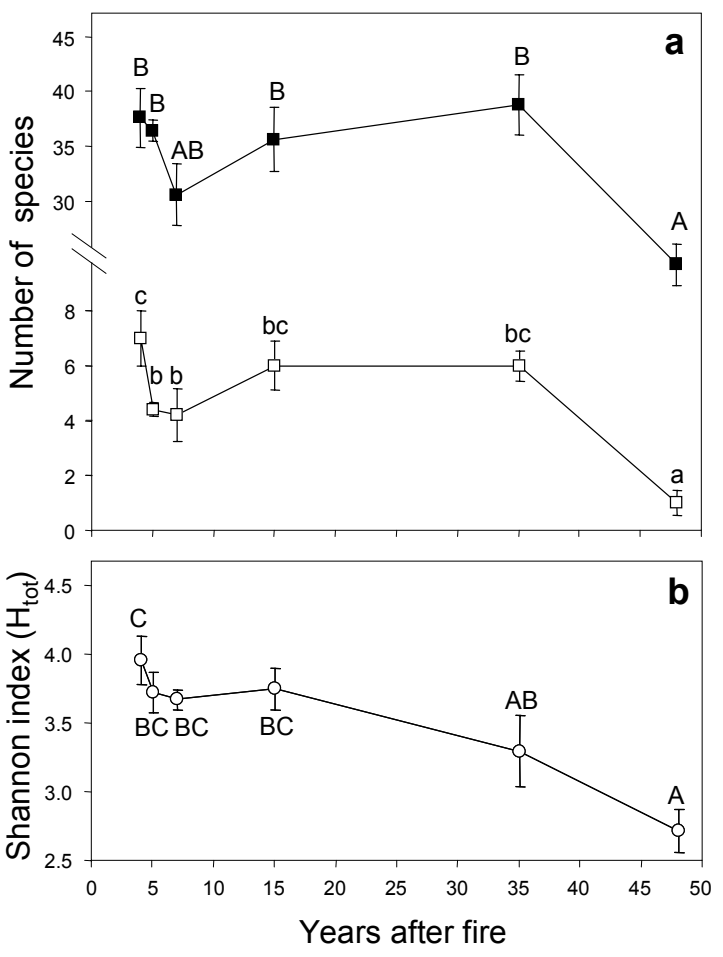

Figure1 without line (as requested by the Referee)

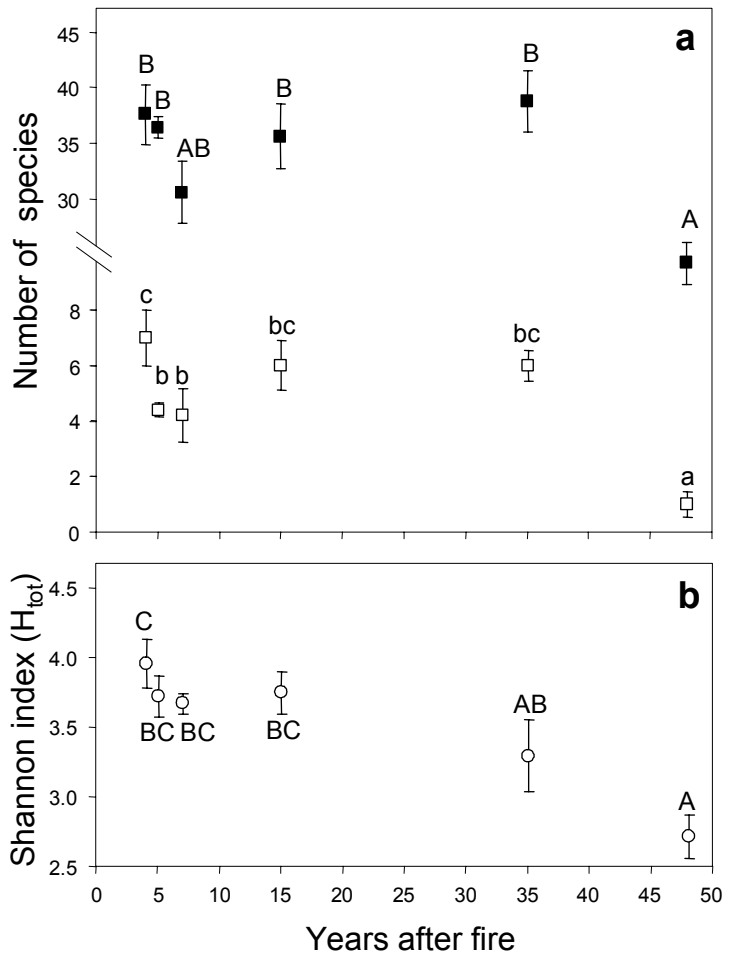


Authors' proposal for Figure1 (no quantitative scale on $\mathrm{x}$ axis)

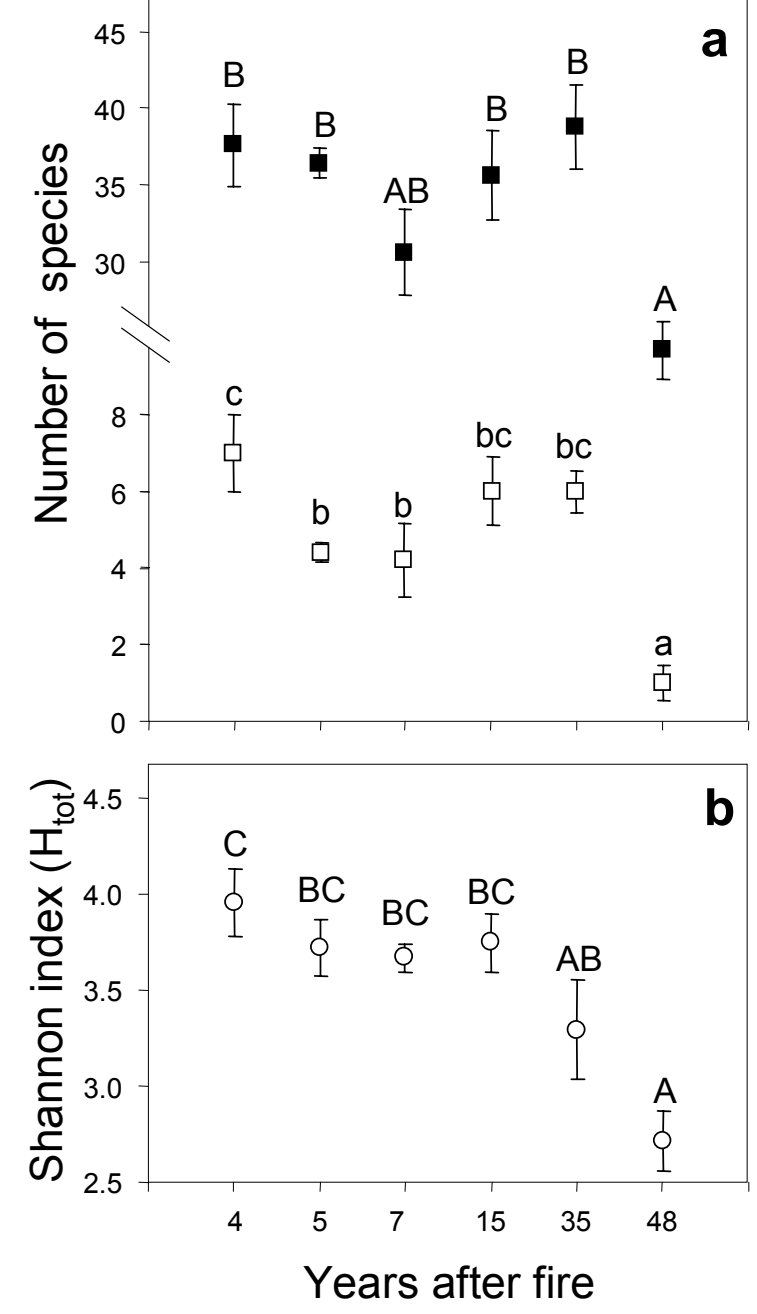


Reviewer \#2: The present manuscript is prepared in a very professional manner and provides a good insight in the research activities. The only weak point is related to the low number of plots that have been sampled in the context of this study and the vague description how the location of the plots in the study area was fixed. Some minor comments are given in order to allow the authors to improve their contribution:

Authors' comments: see details, that address all the general impressions

1) P3 L36: The mean values are valid for which altitude? As the study area is larger it is important to know the variation, instead of the man values perhaps.

Authors' comments: we agree with your observation: a range of precipitation and temperature could be more informative. However, we have not modelled climatic variables in the paper. The aim of reporting climatic data in the description of the study area is to outline the climate of the middle valley (dry inner-alpine valley). e detailed in the text the altitude, mean annual precipitation and mean annual temperature of Aosta weather station, that is the nearest to our studied sites (data from over 100 years of observation). These data were sufficient to illustrate the dry inner-alpine conditions of the studied area. Other weather stations close to the study sites have collected data only from a few years.

Old version:

'Mean annual precipitation is approximately $600 \mathrm{~mm}$, and mean annual temperature is $10^{\circ} \mathrm{C}$.'

New version:

'In the middle Aosta Valley, $20 \mathrm{~km}$ from the study sites, mean annual precipitation is $561.4 \mathrm{~mm}$, and mean annual temperature is $10.6^{\circ} \mathrm{C}$ (Aosta, $583 \mathrm{~m}$ a.s.1.; mean of years 1841-1998) (Mercalli et al. 2003).'

Added in the References:

Mercalli L, Cat Berro D, Montuschi S, Castellano C, Ratti M, Di Napoli G, Mortara G, Guindani N (2003) Atlante climatico della Valle d'Aosta (Climate Atlas of the Aosta Valley). Regione Autonoma Valle d'Aosta, Direzione Protezione Civile, Ufficio Meteorologico, Aosta.

2) P4 L21: Is there some historical information available on the past treatments of the area (records, orthophotos, ...?). This would be important for judge the statement about homogeneity of pre-fire understory communities. Very often a similar management leads to similar structures and species composition. However, it would be important to know, how this past management was done.

Authors' comments: Unfortunately, there are no georeferenced information on past treatments, and old orthophotos (black and white) are of poor quality and not informative to investigate forest structure. However, significant information about past treatments in the area can be found in Camerano at al 2007 (quoted in the text), that confirms our assumption of homogeneity: "The autoecology of Scots pine has favored in the past the application of silvicultural treatments based on clearcut on areas larger than one hectare. These, and the species' ability to rapidly colonize abandoned lands, resulted in the prevalence of even-aged, monolayered stand structures (Camerano at al 2007)" (translated from Italian). We added this sentence to the text.

3) P4 L36: It would be good to know, how the authors avoided the trampling effect during field sampling, as the regeneration sample was investigated in the center of the plot (which is unusual, generally satellite plots are taken from a distance of the center, to avoid that effect...)

Authors' comments: herbaceous vegetation and tree saplings were sparse (see Table 2), so during field work it was quite easy to avoid trampling. During field work only 2 people were simultaneously on any plot, further reducing trampling effects. Other works used a similar sampling design (here after some examples):

Klanderud K. et al. 2010. Recovery of plant species richness and composition after slash-and-burn agriculture in a tropical rainforest in Madagascar. Biodiv Conserv 19:187-204. Each plot consisted of six $5 \times 5 \mathrm{~m}$ sub-plots and each sub-plot had a $1 \times 1 \mathrm{~m}$ quadrat in its centre.

Lundqvist L., Fridman E., 1996. Influence of local stand basal area on density and growth of regeneration in uneven-aged Picea abies stands. Scand J For Res 11 (1-4): 364-369. Basal area of trees of at least $2 \mathrm{~m}$ height within three different radii from the subplot centres was measured.

Belden A.C., Pallardy S. G. (2009) Successional trends and apparent Acer saccharum regeneration failure in an oak-hickory forest in central Missouri, USA. Plant Ecol 204:305-322. "Saplings were sampled in a 0.04 ha nested concentric plot."

4) P7 L37: It is unclear if there are now 5 plots per site or less then that available for the analysis? From Figure 3 it seems, that the number is balanced, however this should be explained.

Authors' comments: the Referee probably meant P4 L37. The number of plot is balanced (5 plot per site). The sentence was rewriter for better clarity.

Old version:

'A total of 30 plots were established and located on the ground with a GPS unit. In each plot ...'

New version: 
'A total of 30 plots (5 per site) were established and located on the ground with a GPS unit. In each plot ...'

5) P7 L35: The "basal area" and the "time since fire" is indirectly related. The larger the trees get, the more time since the last fire has passed. Therefore it might be important to check the significance of the criteria by removing the criteria time since fire or basal area from the GLM analysis.

Authors' comments: at P7 L33-35 we described the univariate models (see 'Methods-Data analysis' and Table 3a). We rewrote the text to explain more clearly that this part relates to Table $3 a$.

Old version:

'Of all variables entered in univariate GLM of ESM species richness, six were significant (Table 3). Light accounted for the highest $\mathrm{D}^{2}(52 \%)$. The number of ESM species was also significantly explained by elevation (37\%), moisture (31\%) and tree basal area $(26 \%)$. Time since fire and percent tree cover were less informative $\left(\mathrm{D}^{2}<20 \%\right)$.'

New version:

'Of all univariate GLM of ESM species richness, only six were significant (Table 3a). The model using light as a predictor accounted for the highest $\mathrm{D}^{2}(52 \%)$. The number of ESM species was also significantly predicted by models based on elevation $(37 \%)$, moisture $(31 \%)$ or tree basal area $(26 \%)$. Time since fire and percent tree cover models were less informative $\left(\mathrm{D}^{2}<20 \%\right)$ '

Using the stepwise GLM procedure (multivariate models, Table $3 b$ ) 'a correlation analysis was previously performed to exclude highly collinear predictors $(R>0.80)$.' (See 'Methods-Data analysis'). The two variables 'time since fire' and 'basal area' were highly correlated $(R=0.91)$ and 'basal area' was removed from the predictors. However the stepwise procedure selected only two variables (Light and Elevation), as reported in Table 3b.

6) P8 L14: Please provide an explanation for "direct succession".

Authors' comments: In the 'Introduction' the process of 'direct succession', or 'autosuccession', was already defined as: 'The high fire resilience of Mediterranean species results in the process of direct succession (or 'autosuccession' sensu Hanes 1971), in which the species present in the pre-fire vegetation regenerate directly after the disturbance, and successively self-thin due to competition as the stand matures (Hanes 1971; Whittaker and Levin 1977, Buhk et al. 2006).'

7) P9 L32: The distance from the unburned edge is also related to the location of the plots within the study area. It would be important to know, how the location of the plots was fixed, and what impact this might have on the results (e.g. centering the plots in the middle....). Especially when checking Table 1 it is not clear how the decision regarding the location was done. The elevation range is sometimes more then $500 \mathrm{~m}$....

Authors' comments: we agree with your observation and improved our description of sampling design in the text. What we did was superimposing on each site (crown fire area) a $25 \times 25 \mathrm{~m}$ grid and randomly extracting 5 grid nodes. Therefore, difference of elevation between plots and distance from the unburned edge were randomly distributed within each site.

Old version:

'Within each fire perimeter, we randomly established 5 circular plots (radius $=12 \mathrm{~m}$ ), providing a minimum distance of $25 \mathrm{~m}$ between plots to avoid spatial autocorrelation. Distance from the unburned edge ranged from ...'

New version:

'Within each fire area, we superimposed a $25 \times 25 \mathrm{~m}$ grid and randomly selected 5 grid points, providing a minimum distance of $25 \mathrm{~m}$ between plots to avoid spatial autocorrelation. Distance from the unburned edge ranged from ...'

8) Figure 2: the symbols should be labeled in a similar way as in figure 3 in order to support the identification of the different sites.

Authors' comments: according to your observation we changed the symbols in Figure 2 . We also changed the captions of Figure 2. 
Old version:

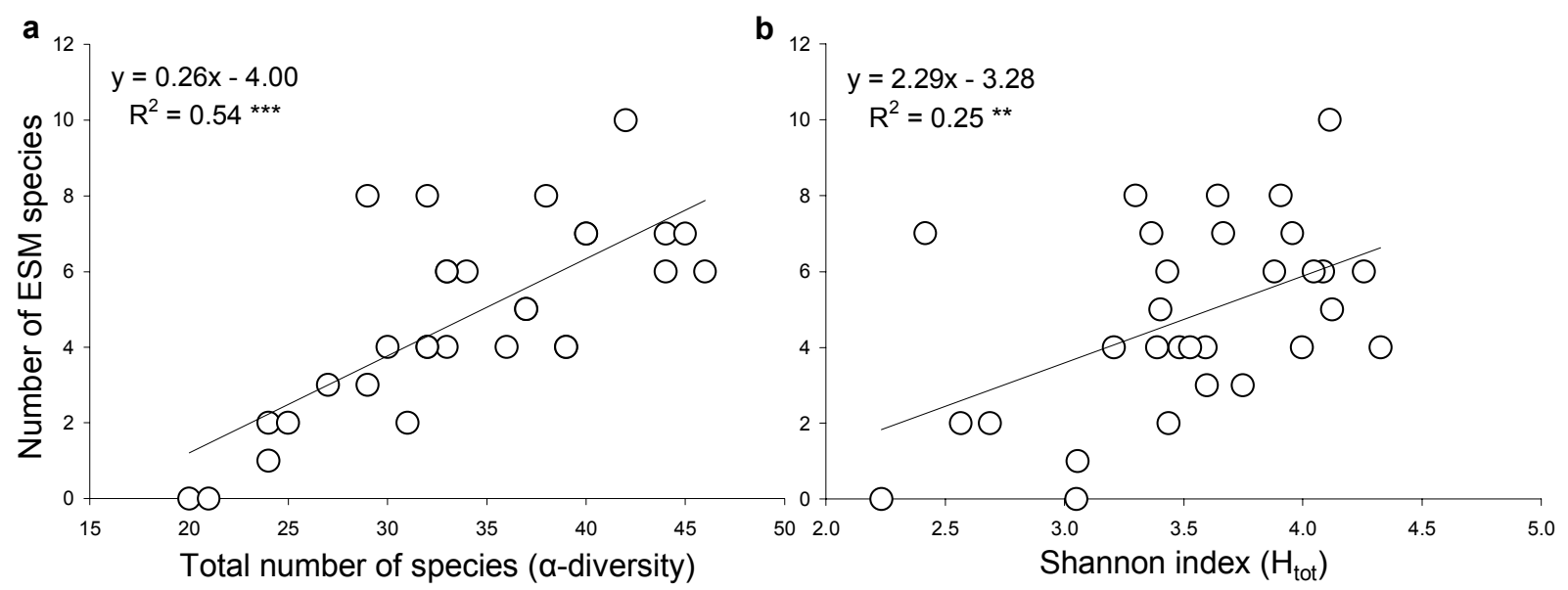

Fig. 2 Linear regression between ESM species richness and a total number of species and $\mathbf{b}$ Shannon index $(\mathrm{n}=30 ; * * \mathrm{p} \leq 0.01, * * * \mathrm{p} \leq 0.001)$

New version:
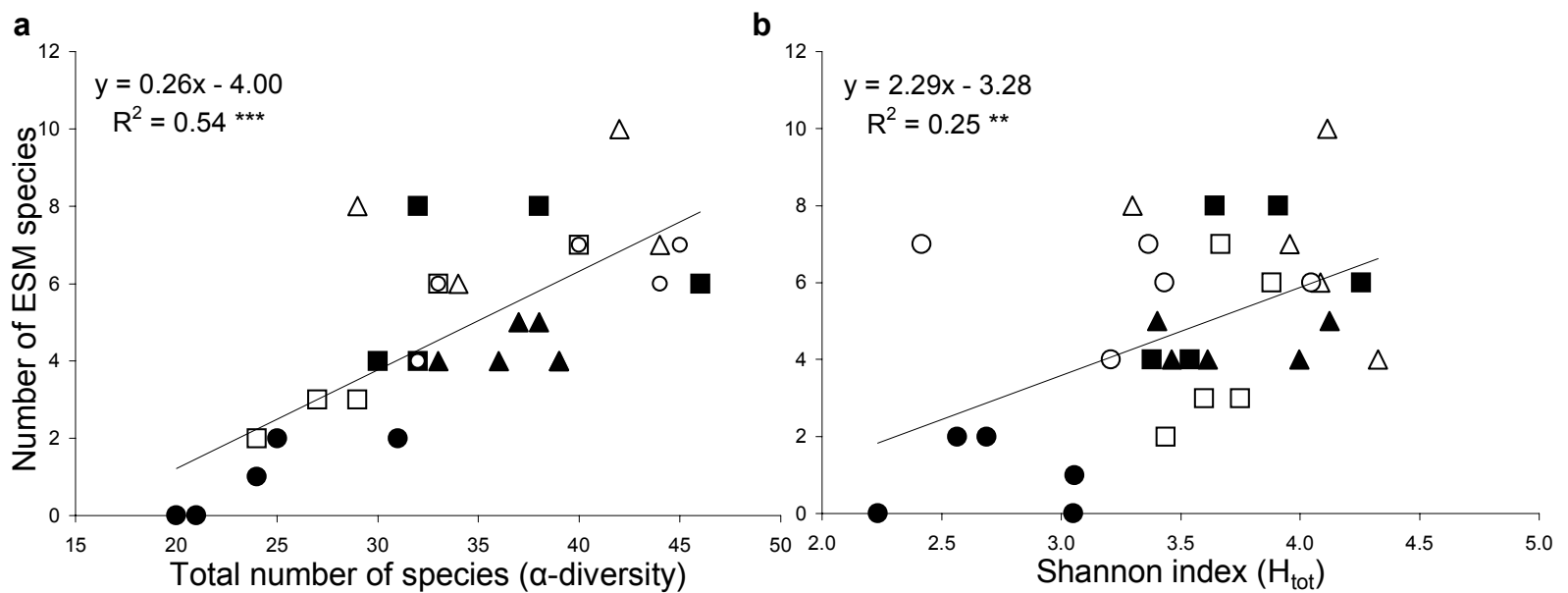

Fig. 2 Linear regression between ESM species richness and a total number of species and $\mathbf{b}$ Shannon index $(\mathrm{n}=30 ; * * \mathrm{p} \leq 0.01, * * * \mathrm{p} \leq 0.001)$. The different symbols are related to time since fire: $(\Delta) 4$ years-old

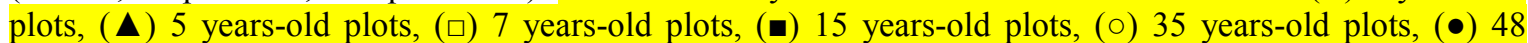
years-old plots. 


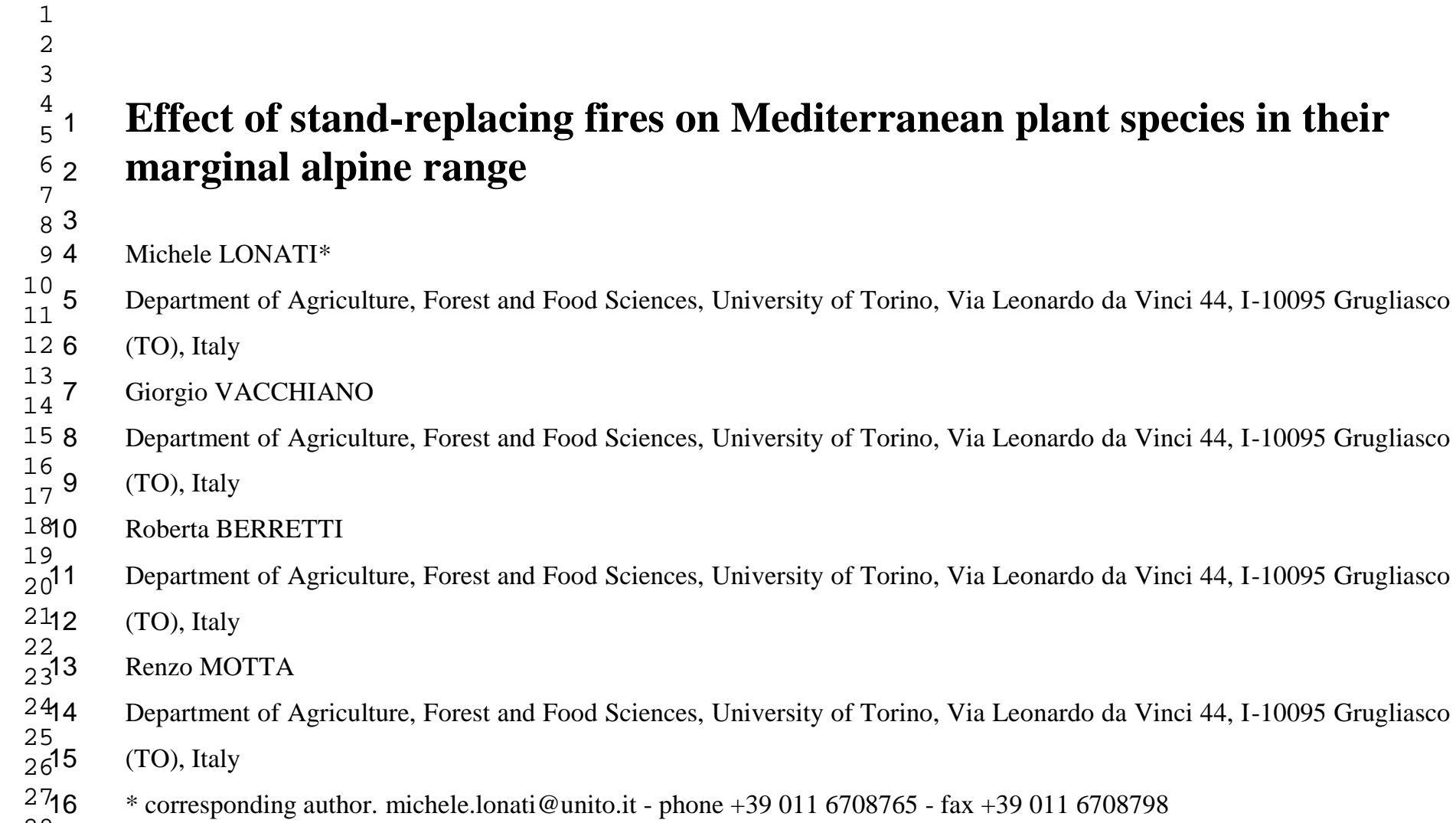




\begin{abstract}
In the southern side of the Alps, many relic species with Mediterranean and sub-Mediterranean distribution were described 73 in mild-winter, fire-prone areas. Very few studies have modeled the importance of environmental factors on their distribution. In this paper, we assessed the effect of fire on the occurrence of euri- and steno-Mediterranean (ESM) species in Pinus sylvestris forests of Aosta Valley (Italy), by analyzing vegetation in a chronosequence of six stand-replacing fires (1962-2006). We analyzed species richness along the chronosequence, and modeled it as a function of time since fire, environment, and stand structure. We observed a strong positive association between ESM and total species richness. Temporal vegetation dynamics did not follow the direct succession pattern that is commonly observed in Mediterranean ecosystems. Two distinct maxima of ESM species richness were observed: (i) short lived, ruderal species (32\% of all ESM species) in the early post-fire stages, and (ii) dry grassland species (54\%) in intermediate stages. The first were facilitated by the consumption of canopy and litter during fire, while the second by delayed tree canopy closure. In multivariate models of ESM species richness, light and elevation were the only significant predictors. Contrary to expectations, time since fire was not significant. Our study suggests that stand-replacing fires play an important role in preserving Mediterranean species in the study area by maintaining an open canopy, and promote local species diversity.
\end{abstract} 8

\title{
Keywords
}

Chronosequence $\bullet$ Conservation $\bullet$ Forest fire $\bullet$ Inner-alpine valleys $\bullet$ Pinus sylvestris L. $\bullet$ Plant diversity 


\section{Introduction}

The southern side of the Alps is characterized by a relatively high plant biodiversity (Aeschimann et al. 2011b), as a results of glacial and postglacial history (Habel et al. 2010). Many mild-winter areas in the southern Alps host xerothermic distribution (Braun-Blanquet 1961; Aeschimannet al. 2004; Schwabe and Kratochwil 2004). Many of these species reach here their northern range limits and, although globally common, they are locally rare, so as to be included in Red Lists as species with high conservation priority (Conti et al. 1997; Moser et al. 2002). At the regional scale ( $\gamma$-diversity), a strong positive correlation was observed between the richness of Mediterranean species and the total species richness (Aeschimann et al. 2011a, 2011b).

Many Mediterranean species have evolved strategies to survive periodic fires (Naveh 1975; Pausas 1999). The high fire resilience of Mediterranean species results in the process of direct succession (or 'autosuccession' sensu Hanes 1971), in which the species present in the pre-fire vegetation regenerate directly after the disturbance, and successively self-thin due to competition as the stand matures (Hanes 1971; Whittaker and Levin 1977, Buhk et al. 2006). This quick regeneration after fire is considered an evolutionary adaptation to the long-lasting influence of fire in the Mediterranean basin (Naveh 1975).

In many parts of the southern Alps, fire has shaped the vegetation since the Neolithic Age (Tinner et al. 1999). In these fireprone areas, pyrophytic Mediterranean species often occur, and fire plays an important role in their maintenance. For example, in southern Switzerland the Mediterranean sageleaf rockrose (Cistus salviifolius) usually occurs on warm rocky outcrops that are permanently treeless, but the species was observed to temporarily extend its occurrence in burnt, tree-free spots (Moretti et al. 2006).

There has been very little work on modelling the distribution of Mediterranean species in their relict alpine range, (Moretti et al. 2006). Most studies were merely descriptive of individual species' ecology or sinecology (e.g., Rey 1989 on Thymus vulgaris in Aosta Valley; Vagge and Biondi 2008 on Juniperus phoenicea and J. thurifera in the Western Alps). To our knowledge, no research to date has modelled the occurrence of the whole Mediterranean biogeographic species group in post-fire vegetation dynamics of the Alps.

The present work aims to assess the role of fire in maintaining Mediterranean species in a dry, inner-alpine valley of the southwestern Alps (Aosta Valley, Italy). We measured the richness of Mediterranean species in a chronosequence of standreplacing fires affecting Scots pine (Pinus sylvestris) forests. The study addresses the following questions: (1) how did Mediterranean species richness change along the chronosequence? (2) how did Mediterranean species richness relate to total species richness? (3) which ecological factors affected Mediterranean species occurrence?

\section{Methods}

1) Study area

The research was carried out in Aosta Valley, northwestern Italy. The regional topography is strongly influenced by late glacial dynamics (Burga 1988). Orographic seclusion, East-West direction, and foëhn winds contribute to a climate with relative low precipitation, typical of inner-alpine regions (Schwabe and Kratochwil 2004). In the middle Aosta Valley, 20 $\mathrm{km}$ from the study sites, mean annual precipitation is $561.4 \mathrm{~mm}$, and mean annual temperature is $10.6^{\circ} \mathrm{C}$ (Aosta, $583 \mathrm{~m}$ a.s.l.; mean of years 1841-1998) (Mercalli et al. 2003). The area is characterized by a complex geology, with dominant 
calcareous schists and subordinate silicate rocks with base-rich or calcium carbonate-rich patches, and rare serpentine

73 Scots pine stands belong to the Ononido-Pinion alliance (Braun-Blanquet 1961; Filipello et al. 1985), that is described as a xerothermic woodland of colline and montane altitudes on alkaline soils, geographically centered on the dry valleys of the inner Alps (Mucina et al. 1993). Scots pine contribute 6\% of forest cover in Aosta Valley (Camerano et al. 2007), but represented 29\% of total burned area in the period 1961-2010 (source: Corpo Forestale Regione Autonoma Valle d'Aosta, low-severity, surface fires (average burned size: $7.6 \mathrm{ha}$ ). An increase in size and intensity of fires has been observed in the last decades (Bovio et al. 2005).

2) Site selection

Vegetation dynamics were assessed along a chronosequence of sites with known fire dates. Although longitudinal observations of permanent plots allow for a better description of vegetation dynamics, chronosequences are considered a valid alternative (e.g. Foster and Tilman 2000; Prévosto et al. 2011), as long as sources of variation other than time are controlled for (Delarze et al. 1992; Capitanio and Carcaillet 2008; Gonzàlez-Tagle et al. 2008).

We selected from a regional database of wildfires in Aosta Valley (source: Corpo Forestale Regione Autonoma Valle d'Aosta, Nucleo Antincendi Boschivi) all crown fires which occurred in Scots pine forests between 1961 and 2010. Selected fire perimeters were georeferenced using Quantum GIS 1.8 (Quantum GIS Development Team, 2012).

In order to minimize sources of variation other than time, we selected six fires according to a space-for-time substitution (Yanai et al. 2003). Fire perimeters were located in the same bioclimatic belt according to Blasi (2010), and were clipped to homogenous elevation (1100 to $1600 \mathrm{~m}$ a.s.l.), slope, aspect (southerly), and relative slope position. Topographic information was obtained from a 10-m resolution Digital Terrain Model. Selected sites were located in the neighbouring municipalities of Verrayes and Saint-Denis $\left(45^{\circ} 46^{\prime} \mathrm{N}, 7^{\circ} 32^{\prime} \mathrm{E}\right)$, with a maximum distance between any two sites of about 5 stands of Scots pine (conducive to crown fire) in ecologically similar sites should be associated to homogenous edaphic conditions. The autoecology of Scots pine has favored in the past the application of silvicultural treatments based on clearcut on areas larger than one hectare. These, and the species' ability to rapidly colonize abandoned lands, resulted in the prevalence of even-aged, monolayered stand structures (Camerano at al 2007).

We used individual fires as treatments, similarly to previous research in post-fire regeneration dynamics (Capitanio and Carcaillet 2008; González-Tagle et al. 2008). Lack of true replication is common in wildfire studies (van Mangtem et al. 2001). Pseudoreplication (i.e., subsampling within the same fire area) could not be entirely avoided, due to the limited number of wildfire events satisfying the conditions for site selection.

Area burned by crown fire was 41 ha on average, and $<8$ ha in three out of six sites. Following regional post-disturbance management policies, all sites had been salvage logged, i.e., all dead trees were harvested after fire (Lindenmayer at al. 2004). Salvage logging in Aosta Valley is ordinarily carried out 1-4 years after fire (Beghin et al. 2010).

At all sites, browsing of the terminal shoots, fraying, and bark stripping on forest regeneration by wild ungulates were very negligible.

3) Data collection 
Sampling was carried out in summer 2011. Within each fire area, we superimposed a $25 \times 25 \mathrm{~m}$ grid and randomly selected 5 grid points, providing a minimum distance of $25 \mathrm{~m}$ between plots to avoid spatial autocorrelation. Distance from the unburned edge ranged from 2 to $169 \mathrm{~m}$. A circular subplot (radius $=5 \mathrm{~m}$ ) was established at the center of each plot for tree regeneration and vegetation analysis. A total of 30 plots ( 5 per site) were established and located on the ground with a GPS unit. In each plot we measured the following variables:

(a) Stand structure and regeneration: we recorded the species, frequency, and diameter at $1.3 \mathrm{~m}$ height (DBH) of all individuals with $\mathrm{DBH} \geq 7.5 \mathrm{~cm}$ (adult trees). Individuals with height $>1.3 \mathrm{~m}$ and $\mathrm{DBH}<7.5 \mathrm{~cm}$ (saplings) and individuals with height $\leq 1.3 \mathrm{~m}$ (seedlings) were measured in each subplot, by recording their DBH and root collar diameter $(\mathrm{RCD})$ respectively;

(b) Ground cover: percent cover of bare soil, rocks, herb, lower shrub (height $\leq 1.3 \mathrm{~m}$ ), upper shrub (height between 1.3 and $5.0 \mathrm{~m}$ ) and tree (height $>5.0 \mathrm{~m}$ ) layers was visually estimated in each subplot;

(c) Vegetation: we visually assessed presence/absence and percent cover of each species in the herbaceous, lower shrub (height $\leq 1.3 \mathrm{~m}$ ), upper shrub (height between 1.3 and $5.0 \mathrm{~m}$ ), and tree layers (height $>5.0 \mathrm{~m}$ ) in each subplot. Species with very low cover $(<1 \%)$ were registered as sporadic ('+'), according to Braun-Blanquet (1932), and subsequently weighted using a $0.3 \%$ conversion value (Tasser and Tappeiner 2005). Floristic nomenclature followed Pignatti (1982).

4) Vegetation and environmental parameters

The recorded species were classified according to their biogeographic distribution (chorotypes) following Pignatti (1982). For each plot, we computed the total number of euri- and steno-Mediterranean (ESM) species. Steno-Mediterranean species show a distribution range strictly related to the Mediterranean basin, while euri-Mediterranean species show a larger distribution range, extending north and east of Mediterranean coastal areas (Pignatti 1982). The phytosociological optimum was associated to each species according to Aeschimann et al. (2004). Characteristic species of each class (or related syntaxa) were defined according to Theurilliat et al. (1994).

For each plot, topographic variables (elevation, slope and aspect) were derived from a 10-m resolution Digital Terrain Model. Aspect was transformed into southness (southness = 180 - aspect $-180 \mid$ ), to provide an interpretable, non circular variable (Chang et al. 2004). Distance to nearest forest edge was calculated in a GIS using crown fire perimeter and GPS position of each plot.

At the plot scale, the following vegetation descriptors were computed: (i) total species richness, i.e., the total number of plant species; (ii) Shannon diversity index $\left(\mathrm{H}_{\mathrm{tot}}\right)$, based on the percent cover of each species; (iii) woody species basal area $\left(\mathrm{BA}, \mathrm{m}^{2} \mathrm{ha}^{-1}\right.$ ), computed using the DBH of adult trees and saplings and the RCD of seedlings; (iv) woody species density (individuals $\mathrm{ha}^{-1}$ ), computed using seedlings, saplings and adult trees; (v) mean Landolt (1977) indicator values for light (L), soil moisture (F) and nutrient content $(\mathrm{N})$, based on species presence/absence (unweighted indices). Previous research suggested that unweighted indices are more responsive to environmental variation than indices weighted on species abundance, because they assign a greater importance to sporadic species with high indicator power (Smartt et al. 1976; Wilson 2012). Mean Landolt indicator values were computed excluding ESM species, in order to ensure total independence between the predictors and the response variable (i.e., ESM species richness).

5) Data analysis 
We assessed between-site differences in woody species density (BA and individuals per hectare), ground cover (percent cover of bare soil, herb, total shrub and tree layers), and biodiversity variables (ESM and total richness, Shannon index) by univariate ANOVA with a Ryan-Einot-Gabriel-Welsch (REGWQ) post-hoc test $(\mathrm{p} \leq 0.05)$. Prior to the analysis, data were tested for normality and homoscedasticity, and transformed as appropriate.

The relationship between ESM species richness and overall biodiversity indices was tested by Pearson's correlation ( $\mathrm{p} \leq$ 0.05). All variable were tested for normality to meet assumptions of the analysis.

A non-canonical Detrended Correspondence Analysis (DCA) was performed on by-segment basis on presence/absence data in order to detect indirect floristic gradient along the chronosequence. The use of DCA on a by-segment basis ensures that distances in the ordination plot approximate ecological distances in terms of species turnover, which is a desirable property in vegetation succession studies (Buhk at al. 2006). Correlation statistics (Pearson's $R, p \leq 0.05$ ) were used to assess relationship of each DCA axis with ESM species richness and time since fire. richness by Generalized Linear Models (GLM). Because of the nature of the dependent variable (count), a Poisson error distribution was assumed and a logarithmic link function was used (McCullagh and Nelder 1983). Predictors were standardized (Z-scores) to allow for analysis of effect size by scrutinizing model parameters (B coefficients). In a first step, a GLM was fitted using one predictor at a time. Subsequently, a multivariate GLM was built using a forward stepwise optimization, i.e., predictors were retained only if their addition resulted in a significant parameter estimate. A correlation analysis was previously performed to exclude highly collinear predictors $(\mathrm{R}>0.80)$. Akaike Information Criterion with small-sample correction (AICC) and percent deviance explained $\left(\mathrm{D}^{2}\right)$ were used as measures of goodness-of-fit. $\mathrm{D}^{2}$ was calculated as (Null deviance-Residual deviance)/Null deviance, where Null deviance is the deviance of an intercept-only GLM, and Residual deviance is the deviance that remains unexplained after model fit.

All the statistical analysis were performed using SPSS 19 (SPSS Inc, Chicago). DCA was performed using CANOCO 4.5 (ter Braak and Šmilauer 1998).

\section{Results}

A total of 165 plant species were found at the sites, among which 28 ESM species (17.0\%) (Appendix 1 in the Supplementary Material). Over a half of ESM species found at the sites (57\%) have their phytosociological optimum in dry, nitrogen-poor grasslands of the class Festuco-Brometea, with many characteristic species belonging to the continental, steppic swards of the order Festucetalia valesiaceae (e.g., Euphorbia seguierana, Ononis pusilla, Koeleria vallesiana). Five ESM species belong to pioneer communities with therophytes (Koelerio-Corynephoretea), and four to nitrophilous, pioneer therophytic communities (Thero-Brachypodietea and Stellarietea mediae). Only three ESM species are associated to forest mantles and mature woody stands (Cratego-Prunetea, Quercetea pubescentis and Pyrolo-Pinetea).

Stand structural variables differed significantly along the chronosequence (Table 2). Regeneration density was initially high (on average about 2240 trees $^{-1} \mathrm{i}^{-1}$ in the first 7 years after fire) due to sprouter species (mainly Quercus pubescens and Populus tremula), and increased 15-35 years after fire, in concomitance with Scots pine establishment. Scots pine showed very scarce regeneration in the first 7 years after fire, but its contribution gradually increased, until it became the dominant species in the mature stand (48 years after fire). Total shrub cover (including saplings) increased up to $40 \%$ in the first 7 years after fire and decreased from 15 years after fire, when pine saplings exceeded $5 \mathrm{~m}$ height as shown by the 
contemporary increase in tree cover (Table 1). A moderate to high herbaceous cover was registered at all stages, without a clear trend along the chronosequence.

73 Total species richness ( $\alpha$-diversity) was high in the younger post-fire sites, but significantly decreased in the 48 years-old site (24 species) (Fig. 1). Similarly, ESM species richness was significantly higher in the first (4 years-old) and intermediate (15-35 years-old) stages of the chronosequence, while in the oldest site they almost disappeared. Shannon index decreased achieved dominance in the tree layer.

A positive and significant correlation was found at the plot scale between ESM and total species richness (Fig. 2a). A similar relationship was found between ESM species richness and the Shannon index (Fig. 2b), although only $25 \%$ of the variability of ESM species richness was explained.

DCA ordination evidenced a clear separation between the different sites of the succession (Fig. 3a). The first two axes explained $18.4 \%$ of total variance (eigenvalues $=0.480$ and 0.230 , respectively).

Axis 1 helped discriminate the youngest ( 4 years-old), intermediate (5 to 35 years-old) and oldest (48 years-old) sites. Axis 2 helped separate the first intermediate ( 5 to 7 years-old) from the second intermediate stages ( 15 to 35 -years-old). The species plot evidenced rather clear groups of species (dotted lines in Fig. 3b).

From a phytosociological point of view, a chronosequence can be described by the following:

I - the youngest site (4 years-old) was dominated by therophytic, early-seral species belonging to the classes KoelerioCorynephoretea (e.g., Minuartia fastigiata, Petrorhagia prolifera), Thero-Brachypodietea (e.g., Linaria simplex, Medicago minima), and Stellarietea mediae (e.g., Ajuga chamaepitys, Conyza canadensis). Also important was the presence of ruderal nitrophilous species from the classes Agropyretea intermedii-repentis (e.g., Convolvulus arvensis, Tragopogon dubius) and Artemisietea vulgaris (e.g., Lactuca serriola, Daucus carota). Only a few of the therophytic species persisted in the intermediate sites (Appendix 1 in the Supplementary Material);

II - in the first intermediate sites (5 to 7 years-old), ruderal species belonging to the class Artemisietea vulgaris (e.g., Carduus nutans, Erigeron annuиs, Senecio inaequidens) decreased, while species from meso-xerophile shrub and fringe communities (Crataego-Prunetea and Trifolio-Geranietea sanguinei) and dry grasslands (Festuco-Brometea) increased. This last group accounted for a total of 32 species, showing also many characteristic species of the class or related syntaxa;

III- in the second intermediate sites (15 to 35 years-old), species from the Festuco-Brometea decreased to 17. We observed an increase of species belonging to the class Crataego-Prunetea (e.g., Prunus spinosa, Prunus mahaleb, Juniperus communis), Querco-Fagetea s.l. (broadleaved forests: e.g., Quercus pubescens, Prunus aviun), and Pyrolo-Pinetea (Scots pine forests: e.g., Saponaria ocymoides, Arctostaphylos uva-ursi and P. sylvestris itself);

IV - in the oldest site (48 years-old) species belonging to the class Festuco-Brometea almost disappeared. We observed many species from the class Querco-Fagetea s.l. (e.g., Fraxinus excelsior, Sorbus aria, Lathyrus montanus) and some from boreal, acidophilous woody communities (Vaccinio-Piceetea excelsae: e.g., Picea excelsa, Melampyrum sylvaticum, Vaccinium myrtillus).

Time since fire was positively correlated to both the first and the second DCA axis (Pearson's $\mathrm{R}=0.61, \mathrm{p}<0.001$, and $\mathrm{R}=$ $0.56, \mathrm{p}<0.001$, respectively). ESM species were abundant in the youngest and intermediate sites (Fig. 3b). A significant, 
negative correlation $(\mathrm{R}=-0.76)$ was detected between DCA1 and the number of ESM species (Fig. 4a). DCA2 did not show any significant correlation with ESM species richness (Fig. 4b).

73 Of all univariate GLM of ESM species richness, only six were significant (Table 3a). The model using light as a predictor accounted for the highest D2 (52\%). The number of ESM species was also significantly predicted by models based on informative (D2 < 20\%). The total number of ESM species increased with light and decreased with increasing time since fire, tree cover, basal area, moisture and, elevation.

Using the stepwise GLM procedure, ESM species richness was best predicted by a combination of light and elevation, which resulted in the lowest AICC (Table 3b).

\section{Discussion}

In the Alpine flora, the proportion of ESM species on the total number of species is $16.1 \%$ on average, ranging from $24 \%$ in the southwestern regions (Maritime Alps, Alpes-de-Haute-Provence and Drôme), to 4\% in Oberbayern (Aeschimann et al. 2011b). In Aosta Valley, the reported proportion of ESM to total number of species is $11.8 \%$; therefore, the studied chronosequence appeared rich in Mediterranean species (17\%), a likely consequence of the submediterranean, mild-winter climate of the study area.

Post-fire vegetation dynamic was typical of secondary succession in temperate regions (Grime 2002; Prévosto et al. 2011), i.e., a transition from annual/ruderal species (belonging to the classes Thero-Brachypodietea, Stellarietea mediae, Agropyretea intermedii-repentis and Artemisietea vulgaris) to perennial herbaceous species characteristic of dry grassland and fringe communities (Festuco-Brometea and Trifolio-Geranietea), to woody shrub species (Crataego-Prunetea), and finally woodland species (Pyrolo-Pinetea and Vaccinio-Picetea).

Despite Scots pine achieved dominance 48 years after fire, pine regeneration was initially delayed (up to 15 years), similarly to observations in other dry areas, both in Mediterranean and Alpine regions (Rodrigo et al. 2004; Moser et al. 2010; VilàCabrera et al. 2012). This behavior is in disagreement with direct succession, which is commonly observed in Mediterranean ecosystems (Trabaud and Lepart 1981; Buhk et al. 2006; Arnan et al. 2007). In autosuccesion, pre-fire species regenerate directly after fire. Pioneer, short-lived species do not prepare the site for the subsequent settlement of later successional species, but they grow side by side in the first post-fire stages (Buhk at al. 2006). In the observed chronosequence, however, ESM species were the components of a replacement process characterized by the gradual substitution of distinct successional stages.

Our results are consistent with observations of ESM species richness in steppic, herbaceous complexes of the order Festucetalia valesiaceae in dry, inner-alpine regions of the central and western Alps (Royer 1991; Schwabe and Kratochwil 2004). In fact, the most important group of ESM species recorded in our work has its phytosociological optimum in dry grasslands of Festuco-Brometea and related syntaxa, including Festucetalia valesiaceae. According to Braun-Blanquet (1961), the association between dry grassland species and forest communities of the Ononido-Pinion alliance in Aosta Valley is a consequence of high light penetration through the low-growing, open tree canopy (see also Mucina et al. 1993; Kelly and Connolly 2000). In the study area, moisture limitations resulted in a sparse canopy cover and a high total species richness up to the intermediate stages of the chronosequence (35 years since fire). By contrast, in the moister Insubric region, species richness was observed to decline already 15 years after disturbance (Delarze et al. 1992), due to the rapid recovery of herbaceous and woody species. 
Along the chronosequence, two distinct maxima of ESM species richness were observed, corresponding to two groups of species differing in post-fire germination strategy:

(a) Annual/ruderal species (32\% of total ESM species recorded) were more abundant in the early successional stages. These species, belonging to the classes Koelerio-Corynephoretea, Thero-Brachypodietea, and Stellarietea mediae, germinate soon after fire, and are facilitated by the combustion of canopy and litter (Schütz 2000). The presence of these species in pre-fire, closed-canopy forest may be explained as a legacy of previous disturbances, or as a result of dispersal from surrounding areas (Halpern et al. 1999; Latzel et al. 2011). Annual ESM species disappeared quickly (5 years after fire), and only few therophytic species persisted in the intermediate post-fire stages. However, their small seeds can persist in the buried soil seed bank, and may cyclically spread after new fires. Therefore, the soil seed bank plays a crucial role to the survival of many ESM species in the studied area, as observed for other rare species (Keddy and Reznicek 1982; Rowell et al. 1982; McCue and Holtsford 1998).

(b) Dry grassland species (57\% of total ESM species recorded), belonging to the class Festuco-Brometea (mainly perennial), were more abundant in intermediate successional stages (15 to 35 years since fire). Calcareous grassland species form a transient seed bank (Willems 1996; Davies and Waite 1998; Kalamees and Zobel 2002), usually confined to the upper soil (Akinola et al. 1998) and consequently susceptible to fire damage (Cespedes at al. 2012). Only a few ESM legume species (e.g., Ononis natrix, O. pusilla: Buhk and Hensen 2005) may be stimulated by fire, which is able to break the physical barriers of their hard-coated seeds (Martin et al. 1975; Auld and O'Connell 1991). Since seed dispersal distance of these species is limited to a few meters or less (Verkaar et al. 1983; Kalamees and Zobel 2002; Becker 2010), their recolonization by seed is slow. Open canopies, however, allow grassland species to persist for many years in sub-optimal forest habitat, as observed by Heubes et al. (2001) in central Europe. In the study area, it is likely that dry, grassland species were well represented in pre-fire, mature stands, as demonstrated by the moderate to high herbaceous cover observed in the older sites. After a fire, these herbs were therefore able to resprout, and replenish the soil seed bank.

In the Alps, at the regional scale ( $\gamma$-diversity), a strong positive association was observed between the richness of Mediterranean species and total species richness (Aeschimann et al. 2011a, 2011b). In our work, the strong correlation between total species richness and the number of ESM species at the plot scale ( $\alpha$-diversity) confirmed the role of Mediterranean species as indicator species (sensu Spellerberg 1994) at the community-ecosystem level (sensu Noss 1990). Total species diversity (Shannon index) was less informative, probably due to the influence of local environmental variables on species cover.

ESM species richness was weakly related to time since fire: the variable was significant in the univariate GLM, but was not selected by the stepwise algorithm. Significant differences in ESM species richness emerged only between the first and last successional stages. This was probably due to the slow re-colonization of dry grassland species.

The number of ESM species was significantly higher under high light conditions and at low elevations, due to their heliophilous and thermophilous character (Thompson 2005). The negative relationship between ESM species richness and stand structural variables, e.g., tree basal area and canopy cover, and ecological variables that favor Scots pine establishment and growth, e.g., moisture (Castro et al. 2004; Moser at al. 2010), was consistent with the light preferences of ESM species. 
Other topographic variables did not affect ESM species richness, conforming to expectations of homogeneity under the adopted site selection criteria. On a larger scale, we expect Mediterranean species to abound at competition-free sites, like 73 rocky outcrops or steep slopes, as described e.g. for Cistus salviifolius in the southern Alps (Moretti et al. 2006). of edge effects suggesting that even small crown fires may be important for ESM establishment and persistence.

\section{Conclusion}

Our study suggests that stand-replacing crown fires play an important role in preserving Mediterranean species and promote local species diversity in the study area. Fires create (i) conditions favorable to the development of short-lived Mediterranean species in the first years after disturbance, and (ii) a spatio-temporal mosaic of dry grassland, shrub, and tree patches, characterized by many perennial Mediterranean grassland species.

Light conditions and elevation were the most important factors affecting the richness of Mediterranean species in the study area. Moreover, soil water limitations in dry, inner-alpine valleys result in a delayed tree canopy closure, and have a positive effect on the maintenance of heliophilous Mediterranean species in the intermediate stages of post-fire succession.

In the light of climate change scenarios, an increase in fire frequency and severity is expected (Zumbrunnen et al. 2009, 2011), promoting the conservation of the Mediterranean species across the Alps.

Acknowledgment This research was partially supported by the Alcotra project 2007/2013 "Foreste di protezione: tecniche gestionali e innovazione nelle Alpi occidentali - Forêts de protection: techniques de gestion et innovation dans les Alpes occidentales", with the co-sponsorship of Piedmont Region and Aosta Valley Autonomous Region. We thank James N. Long and Diego Trucchi for field sampling, Giancarlo Cesti and Corpo Forestale Regione Autonoma Valle d'Aosta, Nucleo Antincendi Boschivi for data provision. 


\section{References}

Aeschimann D, Rasolofo N, Theurillat JP (2011a) Analyse de la flore des Alpes. 1: historique et biodiversité (Analysis of the flora of the Alps. 1: history and biodiversity). Candollea 66:27-55

Aeschimann D, Rasolofo N, Theurillat JP (2011b) Analyse de la flore des Alpes. 2: biodiversité et chorologie (Analysis of the flora of the Alps. 2: biodiversity and chorology). Candollea 66:225-253

Aeschimann D, Lauber K, Moser MD, Theurillat JP (2004) Flora alpina (Flora of the Alps). Zanichelli, Bologna

Akinola MO, Thompson K, Buckland SM (1998) Soil seed bank of an upland calcareous grassland after 6 years of climate and management manipulations. J Appl Ecol 35:544-552

Arnan X, Rodrigo A, Retana J (2007) Post-fire regeneration of Mediterranean plant communities at a regional scale is dependent on vegetation type and dryness. J Veg Sci 18:111-122

Auld TD, O'Connell MA (1991) Predicting patterns of post-fire germination in 35 eastern Australian Fabaceae. Austral J Ecol 16:53-70

Beghin R, Lingua E, Garbarino M, Lonati M, Bovio G, Motta R, Marzano R (2010) Pinus sylvestris forest regeneration under different post-fire restoration practices in the northwestern Italian Alps. Ecol Eng 36:1365-1372

Becker T. (2010) Explaining rarity of the dry grassland perennial Astragalus exscapus. Folia Geobot 45:303-321

Blasi C (ed) (2010) La vegetazione d'Italia (The vegetation of Italy). Palombi \& Partner Srl, Roma

Bovio G, Camia A, Guglielmet E, Cesti G (2005) Piano regionale per la programmazione delle attività di previsione, prevenzione e lotta attiva contro gli incendi boschivi (Regional plan for forecasting, preventing and countering wildfires). Regione Autonoma Valle d'Aosta, Assessorato Agricoltura, Risorse Naturali e Protezione civile, Dipartimento risorse naturali, Corpo forestale, Protezione civile e antincendio.

Braun-Blanquet J (1932) Plant sociology. Ed. 1, McGraw-Hill Book Company, New York and London

Braun-Blanquet J (1961) Die inneralpine Trockenvegetation, von der Provence bis zur Steiermark (Inner-alpine dry vegetation, from Provence to Styria). Fisher, Stuttgart

Buhk C, Hensen I (2005) Lack of hard-seeded species in pre-fire and post-fire seed banks in the region of Murcia (southestern Spain). An Biol 27:29-37

Buhk C, Götzenberg L, Wesche K, Sánchez Gómez P, Hensen I (2006) Post-fire regeneration in a Mediterranean pine forest with historically low fire frequency. Acta Oecol 30:288-298

Burga CA (1988) Swiss vegetation history during the last 18.000 years. New Phytol 110:581-602

Camerano P, Terzuolo PG, Varese P (2007) I tipi forestali della Valle d'Aosta (Forest cover types of Aosta Valley). Compagnia delle Foreste, Arezzo

Capitanio R, Carcaillet C (2008) Post-fire Mediterranean vegetation dynamics and diversity: a discussion of succession models. Forest Ecol Managem 255:431-439

Castro J, Zamora R, Hódar JA (2002) Mechanisms blocking Pinus sylvestris colonization of Mediterranean mountain meadows. J Veg Sci 13:725-731

Cespedes B, Torres I, Urbieta IR, Moreno JM (2012) Effects of changes in the timing and duration of the wet season on the germination of the soil seed bank of a seeder-dominated Mediterranean shrubland. Plant Ecol 213:919-931

Chang C, Lee P, Bai M, Lin T (2004) Predicting the geographical distribution of plant communities in complex terrain: a case study in Fushian Experiment Forest, northeast Taiwan. Ecology 27:577-588 
Conti F, Manzi A, Pedrotti F (1997) Liste rosse regionali delle piante d'Italia (Regional red lists of plants in Italy). Università di Camerino, Dipartimento di Botanica ed Ecologia, Camerino

Davies A, Waite S (1998) The persistence of calcareous grassland species in the soil seed bank under developing and established scrub. Plant Ecol 136:27-39

Delarze R, Caldelari D, Hainard P (1992) Effects of fire on forest dynamics in Southern Switzerland. J Veg Sci 3:55-60

Filipello S, Sartori F, Terzo V, Gardini Peccenini S (1985) Carta della vegetazione dei dintorni di Aosta (Vegetation map of the surroundings of Aosta). Atti Ist Bot e Lab Critt 4:5-25

Foster BL, Tilman D (2000) Dynamic and static view of succession: testing the descriptive power of the chronosequence approach. Plant Ecol 146:1-10

Gonzàles-Tagle MA, Schwendenmann L, Pèrez JJ, Schulz R (2008) Forest structure and woody plant species composition along a fire chronosequence in mixed pine-oak forest in the Sierra Madre Oriental, Northeast Mexico. Forest Ecol Managem 256:161-167

Grime JP (2002) Plant strategies, vegetation processes, and ecosystem properties. Wiley \& Sons, Chichester (UK)

Guyot H (1935) Phytogéographie comparée du Valais et de la vallée d'Aoste (Compared phytogeography of Valais and Aosta Valley). Bull Maurith 52:16-35

Habel JC, Schmitt T, Assmann T (2010) Refugial areas and postglacial colonizations in the Westsern Paleartic. In: Habel JC, Assmann T (eds) Relict species: phylogeography and conservation biology. Springer-Verlag, Berlin Heidelberg, pp 189-193

Halpern CB, Evans SA, Nielson S (1999) Soil seed bank in young, closed-canopy forests of the Olympic Peninsula, Washington: potential contribution to understory reinitiation. Can J Bot 77:922-935

Hanes TL (1971) Succession after fire in the chaparral of southern California. Ecol Monogr 41:27-52

Heubes J, Retzer V, Schmidtlein S, Beierkuhnlein C (2011) Historical Land Use Explains Current Distribution of Calcareous Grassland Species Folia Geobot 46:1-16

Kalamees R, Zobel M (2002) The role of the seed bank in gap regeneration in a calcareous grassland community. Ecology 83:1017-1025

Keddy PA, Reznicek AA (1982) The role of seed banks in the persistence of Ontario's coastal plain flora. Amer J Bot 69:13-22

Kelly DL, Connolly A (2000) A review of the plant communities associated with Scots pine (Pinus sylvestris L.) in Europe, and an evaluation of putative indicator specialist species. Invest Agr Sist Recur For Fuera de Serie 1:15-39

Latzel V, Klimešová J, Doležal J, Pyšek P, Tackenberg O, Prach K (2011) The Association of dispersal and persistence traits of plants with different stages of succession in central European man-made habitats. Folia Geobot 46:289-302

Lindenmayer DB, Foster DR, Franklin JF, Hunter ML, Noss RF, Schmiegelow FA, Perry D (2004) Salvage harvesting policies after natural disturbance. Science 303:1303.

Martin RE, Miller RL, Cushwa CT (1975) Germination response of legume seeds subjected to moist and dry heat. Ecology 56:1441-1445

Marzano R, Garbarino M, Marcolin E, Pividori M, Lingua E (2013) Deadwood anisotropic facilitation on seedling establishment after a stand-replacing wildfire in Aosta Valley (NW Italy). Ecol Eng 51:117-122 
McCue KA, Holtsford TP (1998) Seed bank influences on genetic diversity in the rare annual Clarkia springvillensis (Onagraceae). Amer J Bot 85:30-36

McCullagh P, Nelder JA (1983) Generalized Linear Models. Chapman and Hall, London

Mercalli L, Cat Berro D, Montuschi S, Castellano C, Ratti M, Di Napoli G, Mortara G, Guindani N (2003) Atlante climatico della Valle d'Aosta (Climate Atlas of the Aosta Valley). Regione Autonoma Valle d'Aosta, Direzione Protezione Civile, Ufficio Meteorologico, Aosta.

Moretti M, Conedera M, Moresi R, Guisan A (2006) Modelling the influence of change in fire regime on the local distribution of a Mediterranean pyrophytic plant species (Cistus salviifolius) at its northern range limit. J Biogeogr 33:1492-1502

Moser B, Temperli C, Schneiter G, Wohlgemuth T (2010) Potential shift in tree species composition after interaction of fire and drought in the Central Alps. Eur J For Res 129:625-633

Moser BR, Gygax A, Bäumler B, Wyler N, Palese R (2002) Red list of threatened ferns and flowering plants in Switzerland. OFEFP, Berne

Mucina L, Grabherr G, Wallnöver S (1993) Die Pflanzengesellschaften Österreichs III: Wälder und Gebüsche (Austrian plant communities III: forests and shrublands). Gustav Fischer, Jena

Naveh Z (1975) The evolutionary significance of fire in the Mediterranean region. Vegetatio 29:199-208

Noss RF (1990) Indicators for monitoring biodiversity: a hierarchical approach. Conserv Biol 4:355-364

Pausas JG (1999) Mediterranean vegetation dynamics: modelling problems and functional types. Plant Ecol 140:27-39

Prévosto B, Kuiters L, Römermann MB, Dölle M, Schmidt W, Hoffmann M, Uytvanck JV, Bohner A, Kreiner D, Stadler J, (2011) Impacts of land abandonment on vegetation: successional pathways in European habitats. Folia Geobot 46:303325

Quantum Gis Development Team (2012). Quantum GIS Geographic Information System. Open Source Geospatial Foundation Project (http://qgis.osgeo.org)

Rey C (1989) Le thym vulgaire (Thymus vulgaris L.) du Val d'Aoste: une particularité botanique de haut intérêt (Common thyme (Thymus vulgaris L.) in Aosta Valley: a botanical feature of high relevance). Rev Valdôtaine Hist Nat 43:79-97

Rodrigo A, Retana J, Xavier Pico F (2004) Direct regeneration is not the only response of Mediterranean forests to large fires. Ecology 85:716-729

Rowell, TA, Walters SM, Harvey HS (1982) The rediscovery of the Fen Violet, Viola persicifolia Schreber, at Wicken Fen, Cambridgeshire. Watsonia 14:183-184

Royer JM (1991) Synthese eurosiberienne, phytosociologique et phytogeographique de la classe des Festuco-Brometea (Eurosibiric phytosociological and phytogeographical synthesis of the class Festuco-Brometea). Diss Bot BerlinStuttgart 178:1-296

Schütz W (2000) The importance of seed regeneration strategies for the persistence of species in the changing landscape of Central Europe. Z Ökol Naturschutz 9:73-83

Schwabe A, Kratochwil A (2004) Festucetalia valesiacae communities and xerothermic vegetation complex in the central Alps related to environmental factor. Phytocoenologia 34:329-446

Smartt PFM, Meacock SE, Lambert JM (1976) Investigations into the properties of quantitative vegetational data. II. Further data type comparisions. J Ecol 64:41-78 
Spellerberg IF (1994) Monitoring ecological change. Ed. 2, Cambridge University Press, Cambridge (UK)

Tasser E, Tappeiner U (2005) New model to predict rooting in diverse plant community compositions. Ecol Modelling 185:195-211

ter Braak CJF, Smilauer P (1998) Reference manual and user's guide to Canoco for Windows (version 4). Microcomputer Power, Ithaca (USA)

Theurillat JP, Aeschimann D, Küpfer P, Spichiger R (1994) The higher vegetation units of the Alps. Colloq Phytosoc 23:190-239

Thompson JD (2005) Plant evolution in the Mediterranean. Oxford University Press, Oxford (UK)

Tinner W, Hubschmid P, Wehrli M, Amman B, Conedera M (1999) Long-term forest-fire ecology and dynamics in southern Switzerland. J Ecol 87:273-289

Trabaud L, Lepart J (1981) Changes in the floristic composition of a Quercus coccifera L. garrigue in relation to different fire regimes. Vegetatio 46:105-116

Vagge I, Biondi E (2008) La vegetazione a Juniperus thurifera L. sulle Alpi occidentali (Juniperus thurifera dominated communities in the western Alps). Fitosociologia 45:201-212

van Mangtem P, Schwarts M, Keifer MB (2001) Monitoring fire effects for managed burns and wildfires: coming to terms with pseudoreplication. Nat Areas J 21:266-273

Verkaar HJ, Schenkeveld AJ, van de Klashorst MP (1983) The ecology of short-lived forbs in chalk grasslands: dispersal of seeds. New Phytol 95:335-344

Vilà-Cabrera A, Rodrigo A, Martínez-Vilalta J, Retana J (2012) Lack of regeneration and climatic vulnerability to fire of Scots pine may induce vegetation shifts at the southern edge of its distribution. J Biogeogr 39:488-496

Whittaker RH, Levin SA (1977) The role of mosaic phenomena in natural communities. Theor Populat Biol 12:117-139

Willems JH (1996) Soil seed banks, seedling recruitment and actual species composition in an old and isolated chalk grassland site. Folia Geobot 30:141-156

Wilson JB (2012) Species presence/absence sometimes represent a plant communities as well as species abundance do, or better. J Veg Sci 23:1013-1023

Yanai RD, Currie WS, Goodale CL (2003) Soil carbon dynamics after forest harvest: an ecosystem paradigm reconsidered. Ecosystems 6:197-212

Zumbrunnen T, Bugmann H, Conedera M, Burgi M (2009) Linking forest fire regimes and climate - A historical analysis in a dry inner alpine valley. Ecosystems 12:73-86

Zumbrunnen T, Pezzatti GB, Menéndez P, Bugmann H, Bürgi M, Conedera M (2011) Weather and human impacts on forest fires: 100 years of fire history in two climatic regions of Switzerland. Forest Ecol Managem 261:2188-2199 


\section{Figure captions}

Fig. 1 Mean $( \pm$ SE) of a total species richness ( $\mathbf{})$, ESM species richness ( $\square)$, and b Shannon index ( $\circ)$ at different times since fire. Sites with no letters in common were significantly different (REGWQ post-hoc test, $p \leq 0.05$ )

Fig. 2 Linear regression between ESM species richness and a total number of species and $\mathbf{b}$ Shannon index $(\mathrm{n}=30 ; * * \mathrm{p} \leq$ $0.01, * * * \mathrm{p} \leq 0.001)$. The different symbols are related to time since fire: (B) 4 years-old plots, ( $\boldsymbol{\Delta}$ ) 5 years-old plots, ( $\square$ ) 7 years-old plots, (ロ) 15 years-old plots, ( $(\circ) 35$ years-old plots, $(\bullet) 48$ years-old plots.

Fig. 3 DCA ordination of a sample plots (different symbols in relation to time since fire) and $\mathbf{b}$ species. Species labels are centred on scores, with minor adjustments to avoid text overlap. Gray circles and bold labels identify ESM species. Dotted lines evidence separations between species groups. Species codes: Aab: Artemisia absinthium. Aag: Alyssum argenteum. Aal: Ailanthus altissima. AAR: Acinos arvensis. AAY: Alyssum alyssoides. Aca: Achnatherum calamagrostis. ACH: Ajuga chamaepitys. Acm: Artemisia campestris. Aco: Achillea collina. Adi: Antennaria dioica. Agl: Arabis glabra. Ahi: Arabis hirsuta. Ali: Anthericum liliago. AMO: Astragalus monspessulanus. Ano: Achillea nobilis. Aon: Astragalus onobrychis. Aov: Amelanchier ovalis. Apy: Ajuga pyramidalis. Aru: Asplenium ruta-muraria. Auv: Arctostaphylos uva-ursi. Avl: Artemisia vulgaris. AVU: Anthyllis vulneraria subsp. polyphylla. Ber: Bromus erectus. Bla: Biscutella laevigata. Bpe: Betula pendula. Bra: Bupleurum ranunculoides. Bru: Brachypodium rupestre. Bvu: Berberis vulgaris. CAB: Colutea arborescens. Cal: Chenopodium album. Cap: Clematis alpina. Car: Cirsium arvense. Cav: Convolvulus arvensis. Cca: Conyza canadensis. Cer: Cirsium eriophorum. Cgr: Chrysopogon gryllus. Chu: Carex humilis. CMI: Chaenorhinum minus. Cnu: Carduus nutans. Cro: Campanula rotundifolia. Csc: Centaurea scabiosa. Ctr: Centaurea triumfetti. Cut: Carlina utzka. Cva: Calamagrostis varia. Cvi: Clematis vitalba. Cvl: Crupina vulgaris. Cvr: Coronilla varia. Cvu: Carlina vulgaris. Dca: Daucus carota. Dte: Diplotaxis tenuifolia. Eac: Erigeron acer. Ean: Epilobium angustifolium. Eat: Epipactis atropurpurea. Eau: Erigeron annuus. ECA: Eryngium campestre. Ecy: Euphorbia cyparissias. Ena: Erucastrum nasturtiifolium. Erh: Erysimum rhaeticum. ESE: Euphorbia seguierana. Evu: Echium vulgare. Far: Festuca arundinacea. FCI: Festuca cinerea. Fex: Fraxinus excelsior. Fpr: Fumana procumbens. Fva: Festuca valesiaca. Fve: Fragaria vesca. Gap: Galium aparine. Gcn: Gymnadenia conopsea. GCO: Galium corrudifolium. Gve: Galium verum. Hco: Hippocrepis comosa. Hfo: Helleborus foetidus. Hnu: Helianthemum nummularium subsp. obscurum. Hpe: Hieracium peletieranum. Hpi: Hieracium piloselloides. Hpr: Hypericum perforatum. Hsy: Hieracium sylvaticum. Hto: Hieracium tomentosum. Ico: Inula conyza. Jco: Juniperus communis. Kpy: Koeleria pyramidata. Ksa: Kernera saxatilis. KVA: Koeleria vallesiana. LCO: Leopoldia comosa. Lcr: Lotus corniculatus. Lde: Larix decidua. Lhi: Leontodon hispidus. Lmo: Lathyrus montanus. LPE: Lactuca perennis. Lse: Lactuca serriola. Lsi: Laserpitium siler. LSM: Linaria simplex. Lvu: Ligustrum vulgare. MCI: Melica ciliata. Mfa: Medicago sativa subsp. falcata. MFS: Minuartia fastigiata. Mlu: Medicago lupulina. MMI: Medicago minima. Mof: Melilotus officinalis. Msa: Medicago sativa subsp. sativa. Msy: Melampyrum sylvaticum. Oca: Orobanche caryophyllacea. Oha: Oxytropis halleri. Ola: Odontites lanceolata. OLU: Odontites lutea. ONA: Ononis natrix. Opi: Oxytropis pilosa. OPU: Ononis pusilla. Ore: Ononis repens. Oro: Ononis rotundifolia. Ovi: Onobrychis viciifolia. Pav: Prunus avium. Pch: Polygala chamaebuxus. Pex: Picea excelsa. Pgr: Prunella grandiflora. Phi: Picris hieracioides. Pma: Prunus mahaleb. Pni: Populus nigra. Por: Peucedanum oreoselinum. Ppa: Poa pratensis. Pph: Phleum phleoides. PPR: Petrorhagia prolifera. PSA: Petrorhagia saxifraga. Psp: Prunus spinosa. Psx: Pimpinella saxifraga. Psy: Pinus sylvestris. Pta: Potentilla tabernaemontani. Ptr: Populus tremula. Pun: Pinus uncinata. Qpu: Quercus pubescens. Rca: Rosa canina. Rid: Rubus idaeus. Rul: Rubus spp. Sar: Sorbus aria. Sca: Salix caprea. Sgr: Scabiosa gramuntia. Sin: Senecio inaequidens. SIT: Silene italica. Smi: Sanguisorba minor. Smo: Sedum montanum. Snu: Silene nutans. Soc: Saponaria ocymoides. Sot: Silene otites. Spe: Stipa pennata. SPR: Salvia pratensis. Sre: Stachys recta. Ste: Sempervivum tectorum. TCH: Teucrium chamaedrys. TCR: Tragopogon crocifolius. Tdu: Tragopogon dubius. Thu: Thymus humifusus. Tla: Taraxacum laevigatum. Tli: Thesium linophyllon. Tme: Trifolium medium. Tmo: Teucrium montanum. Tof: Taraxacum officinale. TVU: Thymus vulgaris. Var: Viola arvensis. Vly: Verbascum lychnitis. Vmy: Vaccinium myrtillus. Vof: Veronica officinalis. Vri: Viola riviniana. Vru: Viola rupestris. Vsa: Vicia sativa. Vth: Verbascum thapsus.

Fig. 4 Correlation between the number of ESM species and DCA scores on $\mathbf{a}$ axis1 and $\mathbf{b}$ axis 2 (Pearson correlation; ns = not significant) 
41 Elettronic supplemental material (ESM1.xls):

5

$6^{2}$

73

8 9 105 11

12 13
Appendix 1 Code, life form, phytosociological optimum, occurrence, and abundance of each species recorded at the study sites. Nomenclature follows Pignatti (1982). Species were divided in two groups: euri/steno-Mediterranean (ESM), and other biogeographic groups. $\mathrm{T}=$ therophyte, $\mathrm{B}=$ biennial, $\mathrm{G}=$ geophyte, $\mathrm{H}=$ hemicryptophyte, $\mathrm{CH}=$ chamaephyte, $\mathrm{P}=$ phanerophyte. 
FIG. 1 (original file PowerPoint MSOffice2003)
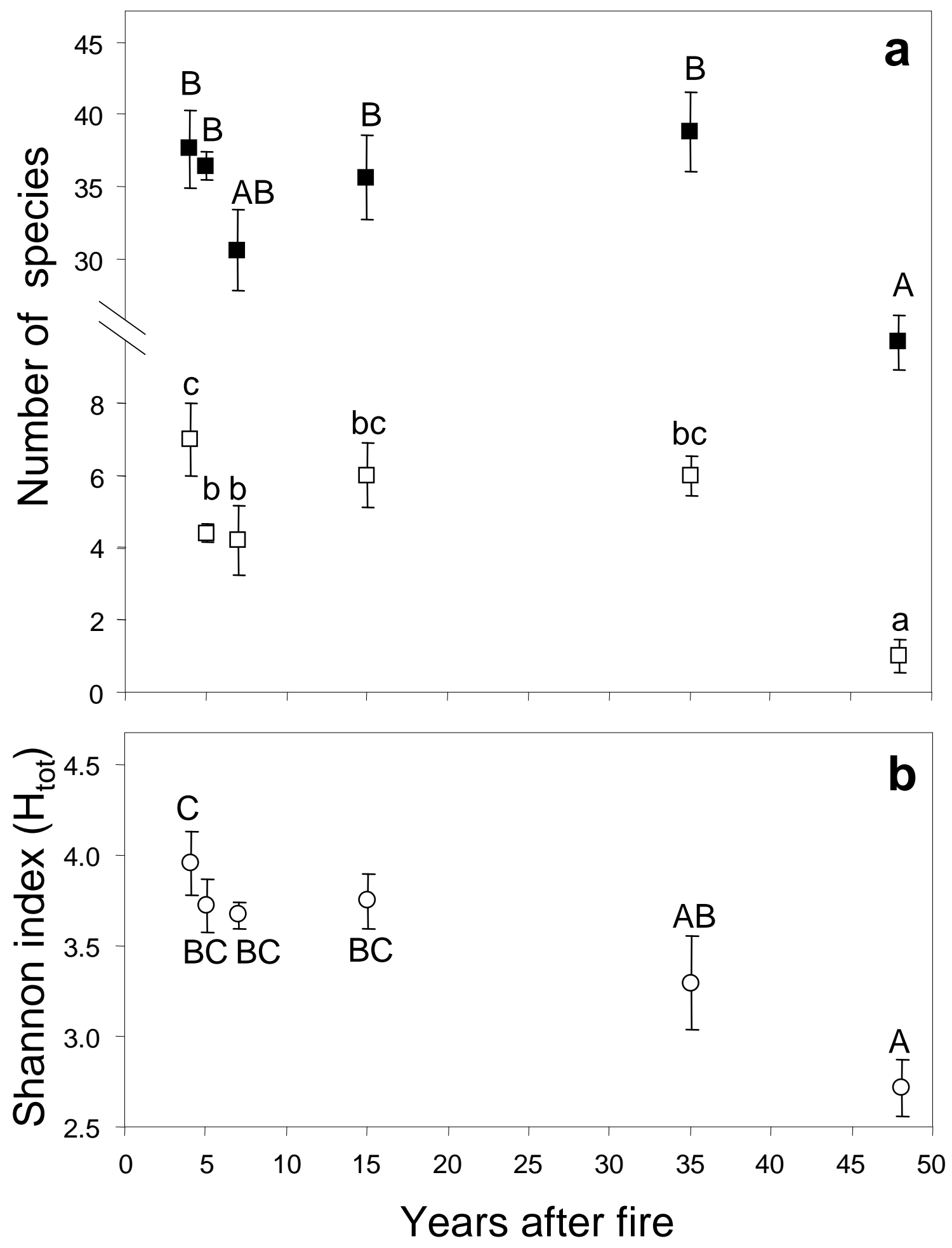

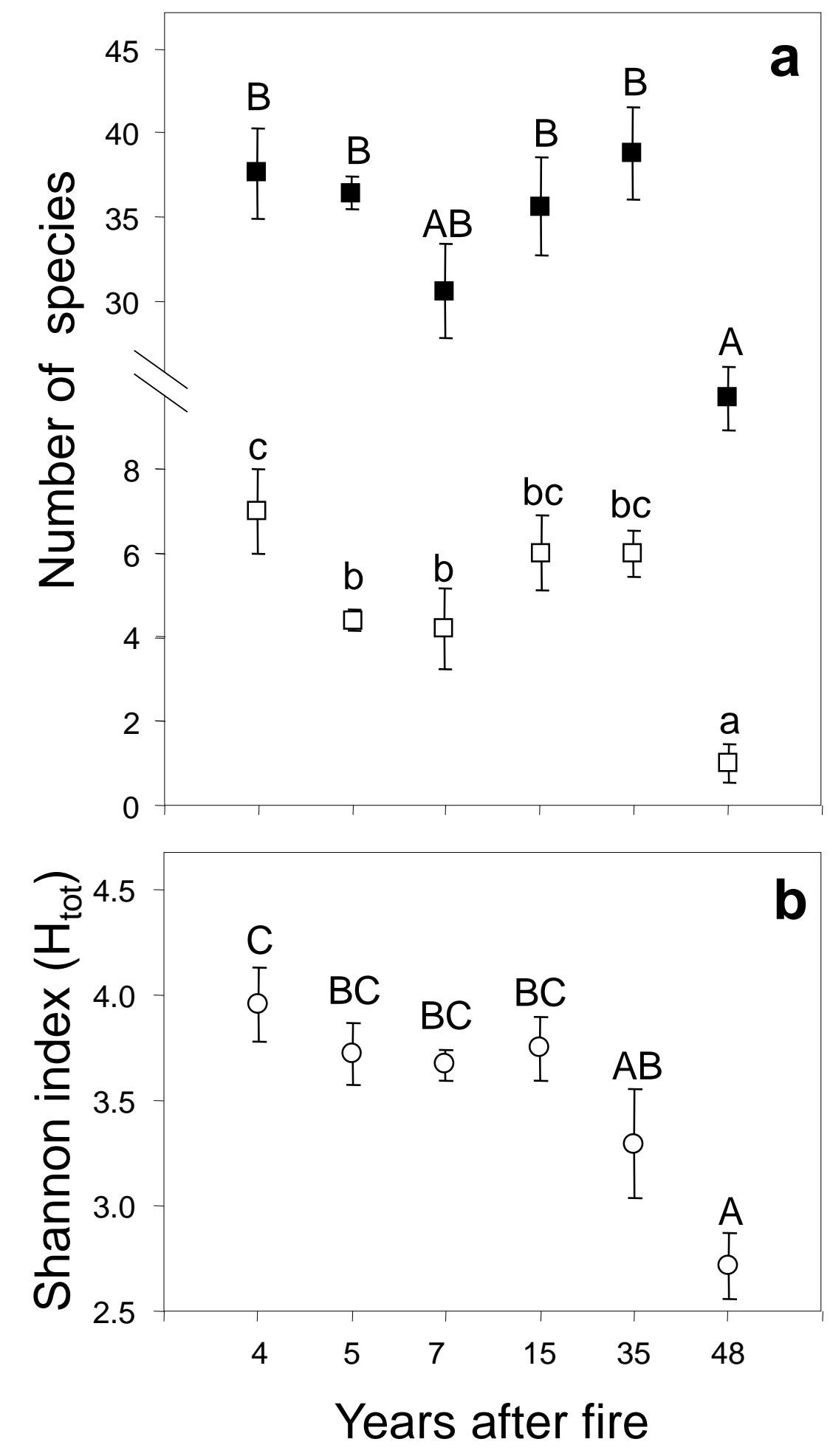
FIG. 2 (original file Excel MSOffice2003)

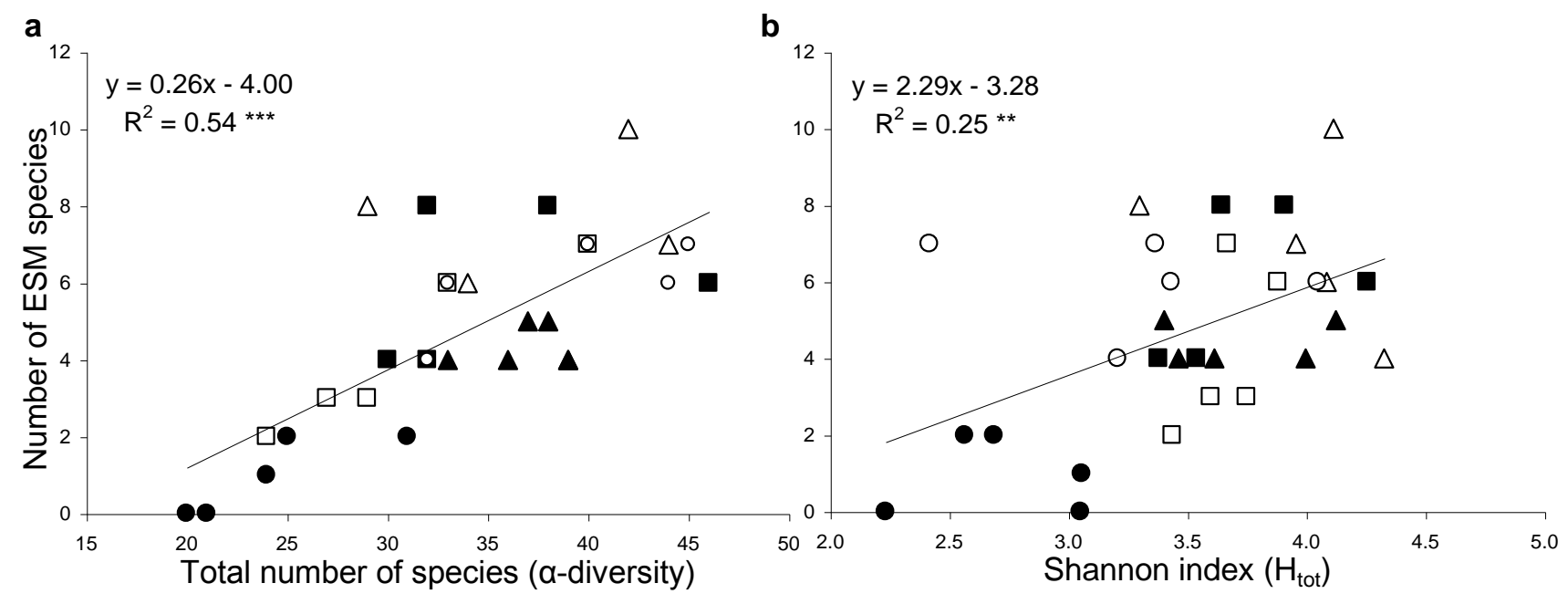




\begin{tabular}{|c|c|c|c|c|c|}
\hline & & & \multicolumn{3}{|c|}{ n_steeur_rntot_specie Htot } \\
\hline plot01 & 0.4471 & 0.9187 & 8 & 29 & 3.297922 \\
\hline plot02 & 0.3201 & 1.4994 & 7 & 44 & 3.956168 \\
\hline plot03 & 0 & 1.4294 & 10 & 42 & 4.113935 \\
\hline plot04 & 0.2586 & 0.8664 & 6 & 34 & 4.085528 \\
\hline plot05 & 0.1912 & 0 & 4 & 39 & 4.326149 \\
\hline plot06 & 2.0877 & 0.5367 & 4 & 36 & 3.995833 \\
\hline plot07 & 1.7981 & 0.3625 & 4 & 33 & 3.462399 \\
\hline plot08 & 1.7765 & 0.2528 & 4 & 39 & 3.61213 \\
\hline plot09 & 1.7685 & 0.2915 & 5 & 37 & 3.401677 \\
\hline plot10 & 1.7195 & 0.6033 & 5 & 38 & 4.123186 \\
\hline plot11 & 2.3025 & 0.7698 & 6 & 33 & 3.881335 \\
\hline plot12 & 2.2996 & 0.7381 & 7 & 40 & 3.666051 \\
\hline plot13 & 2.3361 & 0.7144 & 3 & 27 & 3.598292 \\
\hline plot14 & 2.4764 & 0.9113 & 2 & 24 & 3.437279 \\
\hline plot15 & 2.6488 & 0.5549 & 3 & 29 & 3.748663 \\
\hline plot16 & 1.5161 & 1.0003 & 4 & 32 & 3.378288 \\
\hline plot17 & 1.1455 & 0.9256 & 8 & 38 & 3.906621 \\
\hline plot18 & 1.6838 & 1.1842 & 8 & 32 & 3.64303 \\
\hline plot19 & 1.4661 & 0.8383 & 6 & 46 & 4.255176 \\
\hline plot20 & 1.8635 & 1.1024 & 4 & 30 & 3.538155 \\
\hline plot21 & 1.4445 & 2.0297 & 4 & 32 & 3.208002 \\
\hline plot22 & 1.6925 & 2.2013 & 7 & 40 & 3.364782 \\
\hline plot23 & 1.3491 & 1.8184 & 6 & 33 & 3.432826 \\
\hline plot24 & 1.6856 & 1.9611 & 6 & 44 & 4.045512 \\
\hline plot25 & 1.8999 & 1.8768 & 7 & 45 & 2.416108 \\
\hline plot26 & 2.8416 & 1.5048 & 2 & 25 & 2.565162 \\
\hline plot27 & 3.6269 & 0.8911 & 1 & 24 & 3.056024 \\
\hline plot28 & 3.7626 & 1.1018 & 0 & 20 & 2.231995 \\
\hline plot29 & 3.2878 & 0.5856 & 0 & 21 & 3.050584 \\
\hline plot30 & 3.2231 & 1.4562 & 2 & 31 & 2.68737 \\
\hline
\end{tabular}

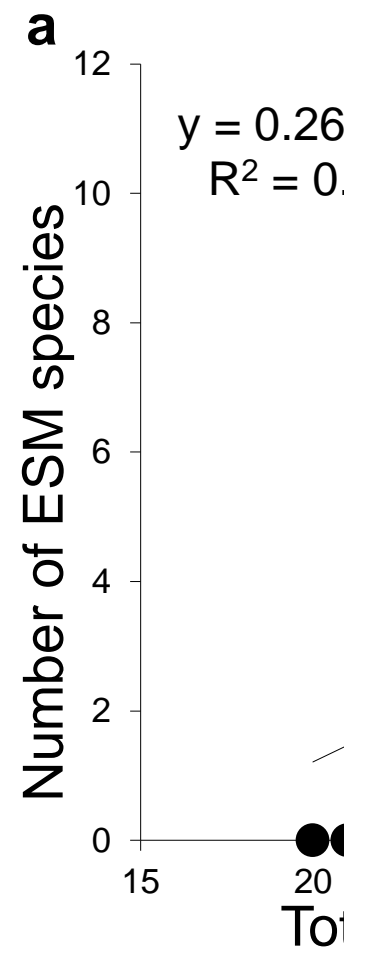




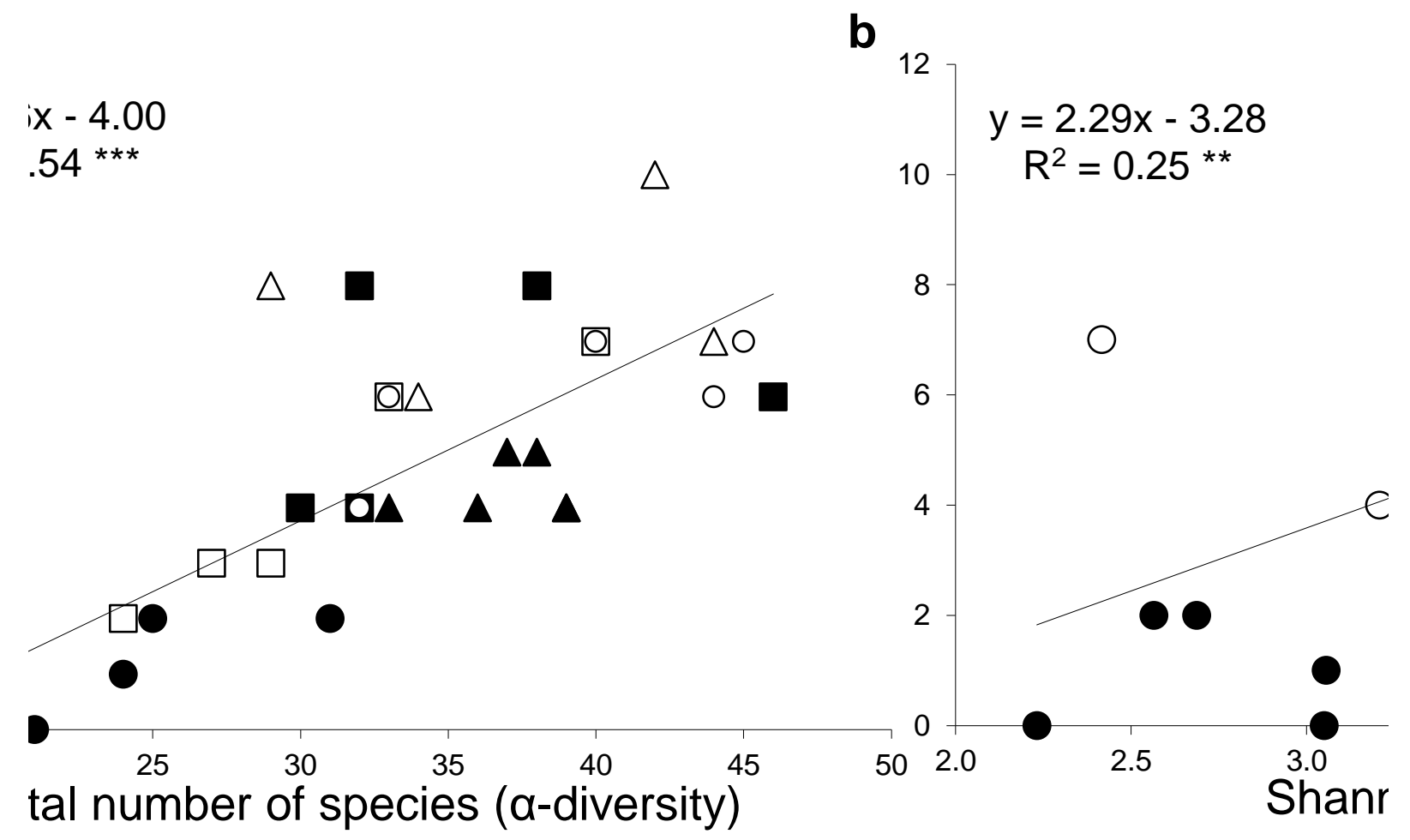


$\triangle$

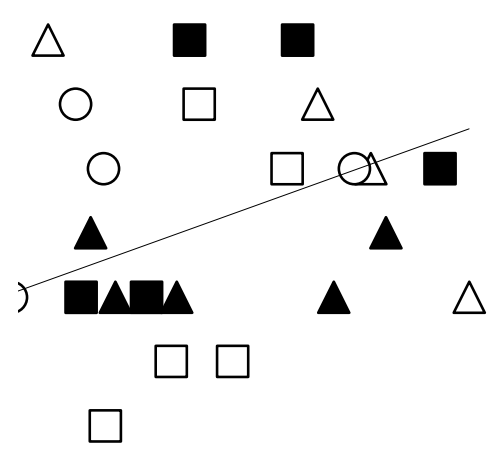

$3.5 \quad 4.0$

$\begin{array}{ll}4.5 & 5.0\end{array}$

ion index $\left(\mathrm{H}_{\text {tot }}\right)$ 
FIG. 3 (original file PowerPoint MSOfice2003)
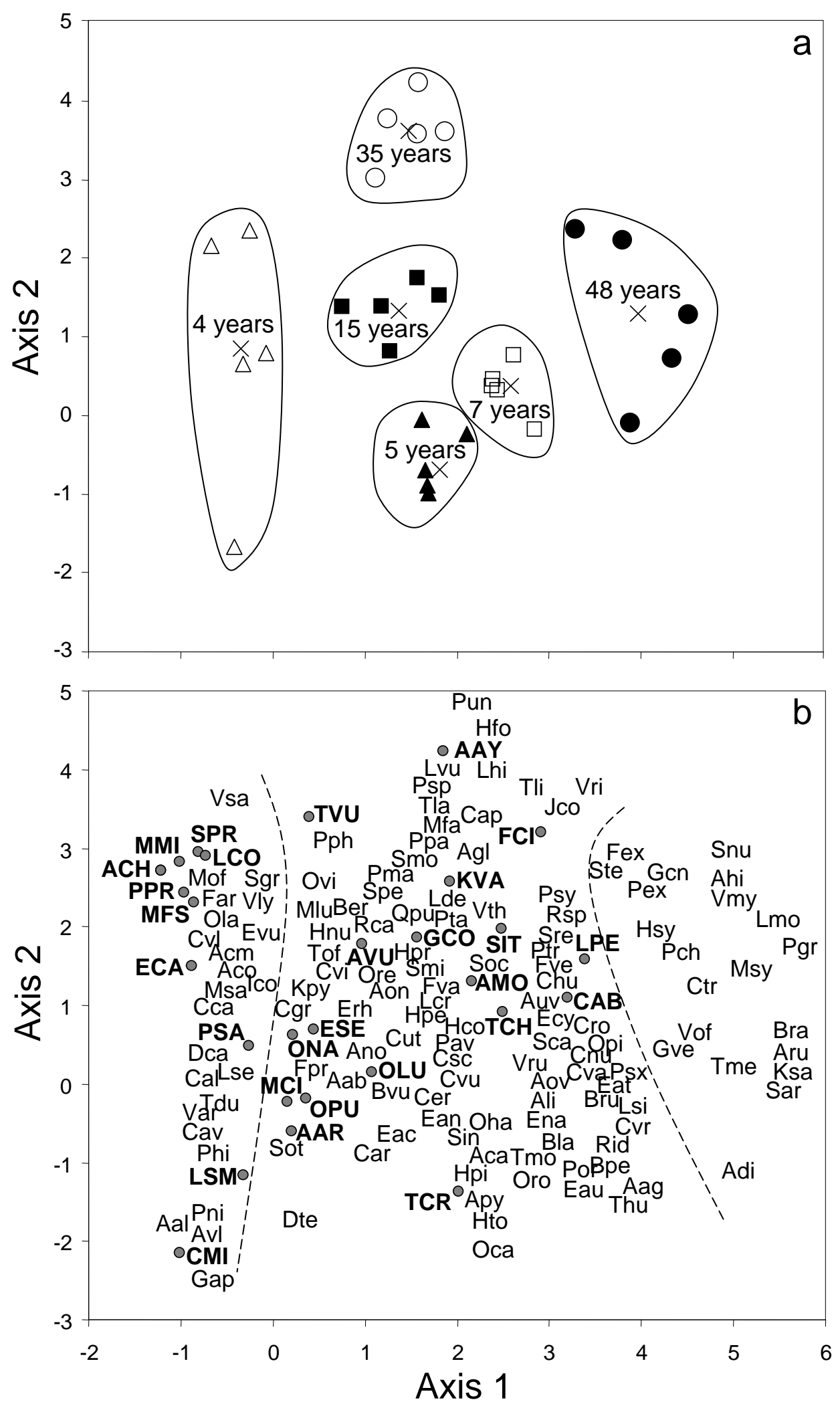

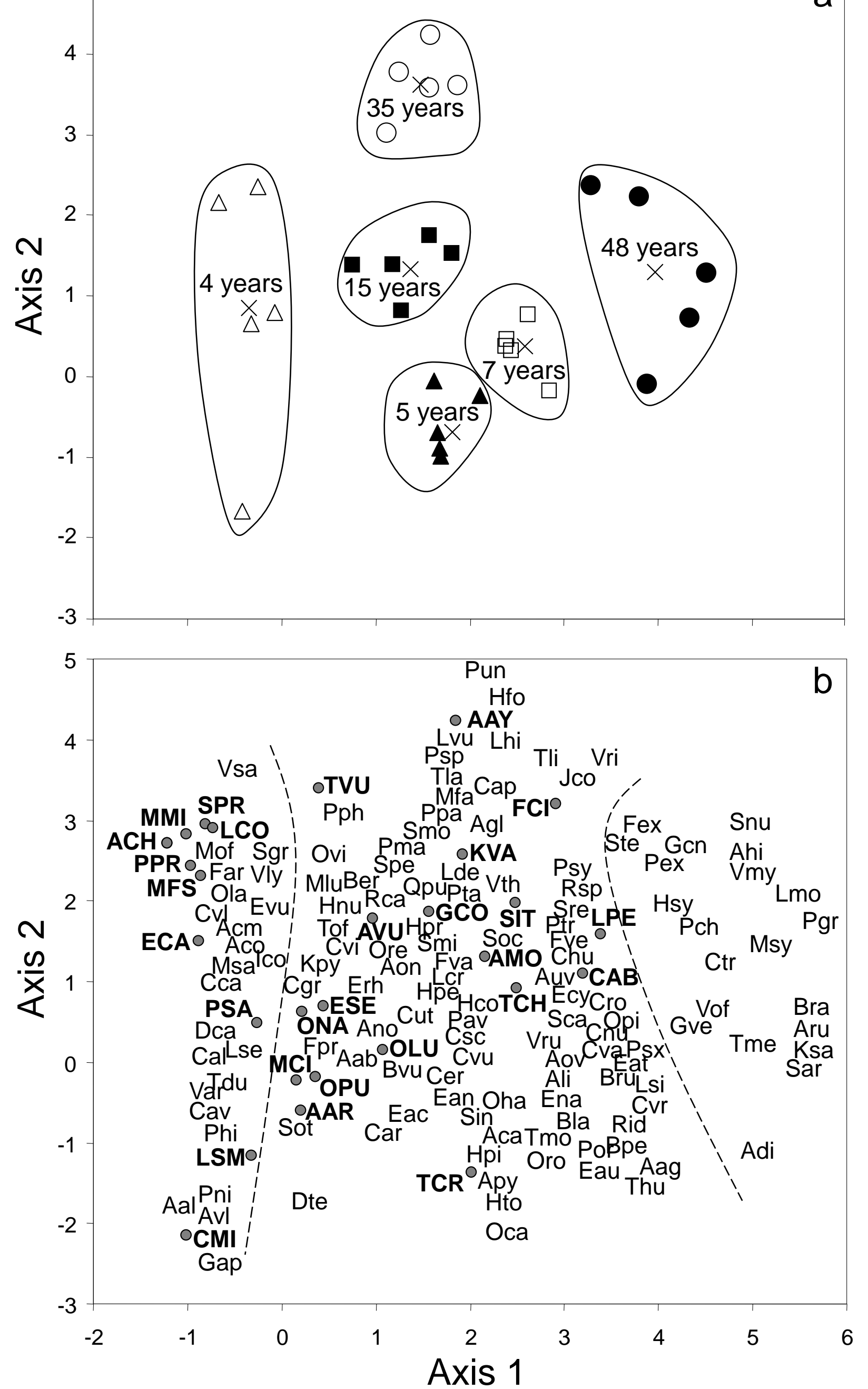
FIG. 4 (original file Excel MSOffice2003)

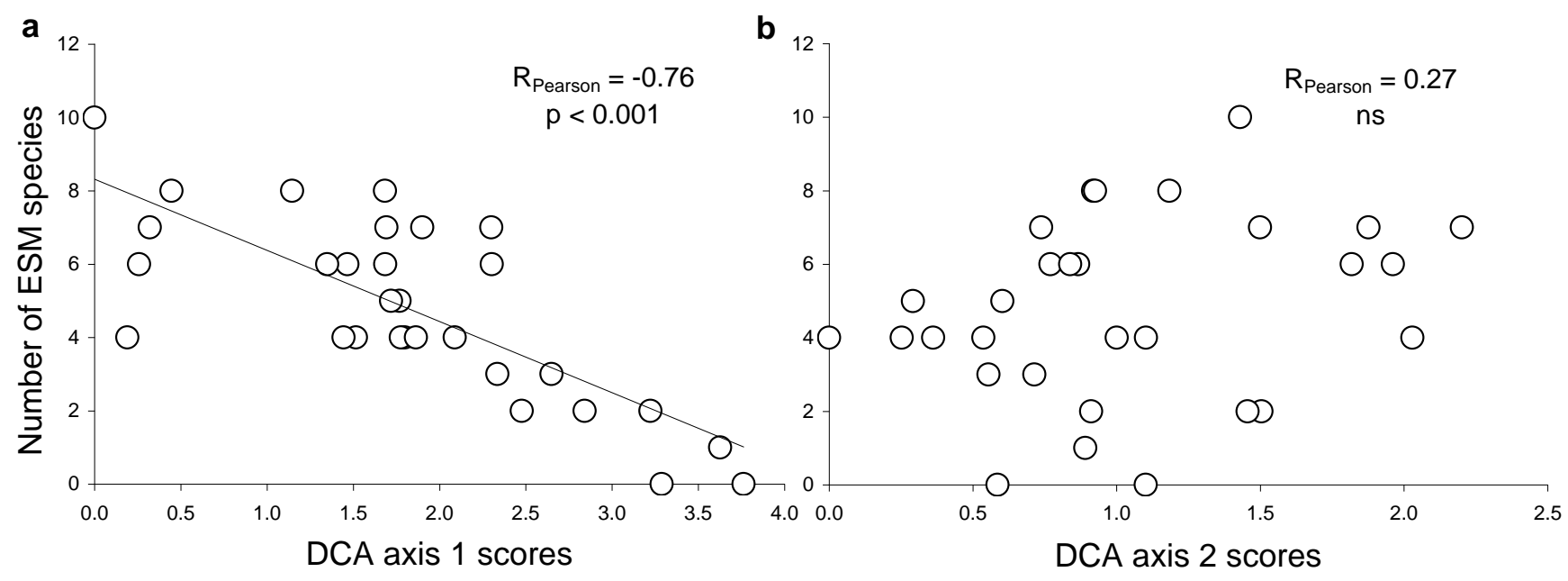




\begin{tabular}{lrrr} 
& ax1 & \multicolumn{2}{c}{ ax2steeur_norub } \\
plot01 & 0.4471 & 0.9187 & 8 \\
plot02 & 0.3201 & 1.4994 & 7 \\
plot03 & 0 & 1.4294 & 10 \\
plot04 & 0.2586 & 0.8664 & 6 \\
plot05 & 0.1912 & 0 & 4 \\
plot06 & 2.0877 & 0.5367 & 4 \\
plot07 & 1.7981 & 0.3625 & 4 \\
plot08 & 1.7765 & 0.2528 & 4 \\
plot09 & 1.7685 & 0.2915 & 5 \\
plot10 & 1.7195 & 0.6033 & 5 \\
plot11 & 2.3025 & 0.7698 & 6 \\
plot12 & 2.2996 & 0.7381 & 7 \\
plot13 & 2.3361 & 0.7144 & 3 \\
plot14 & 2.4764 & 0.9113 & 2 \\
plot15 & 2.6488 & 0.5549 & 3 \\
plot16 & 1.5161 & 1.0003 & 4 \\
plot17 & 1.1455 & 0.9256 & 8 \\
plot18 & 1.6838 & 1.1842 & 8 \\
plot19 & 1.4661 & 0.8383 & 6 \\
plot20 & 1.8635 & 1.1024 & 4 \\
plot21 & 1.4445 & 2.0297 & 4 \\
plot22 & 1.6925 & 2.2013 & 7 \\
plot23 & 1.3491 & 1.8184 & 6 \\
plot24 & 1.6856 & 1.9611 & 6 \\
plot25 & 1.8999 & 1.8768 & 7 \\
plot26 & 2.8416 & 1.5048 & 2 \\
plot27 & 3.6269 & 0.8911 & 1 \\
plot28 & 3.7626 & 1.1018 & 0 \\
plot29 & 3.2878 & 0.5856 & 0 \\
plot30 & 3.2231 & 1.4562 & 2
\end{tabular}

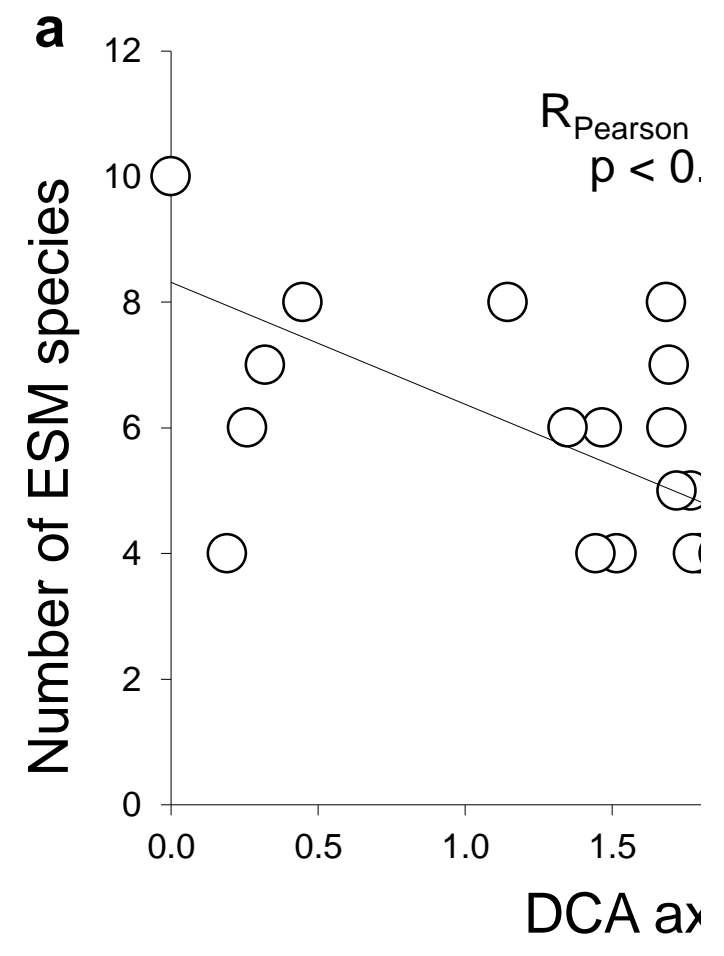




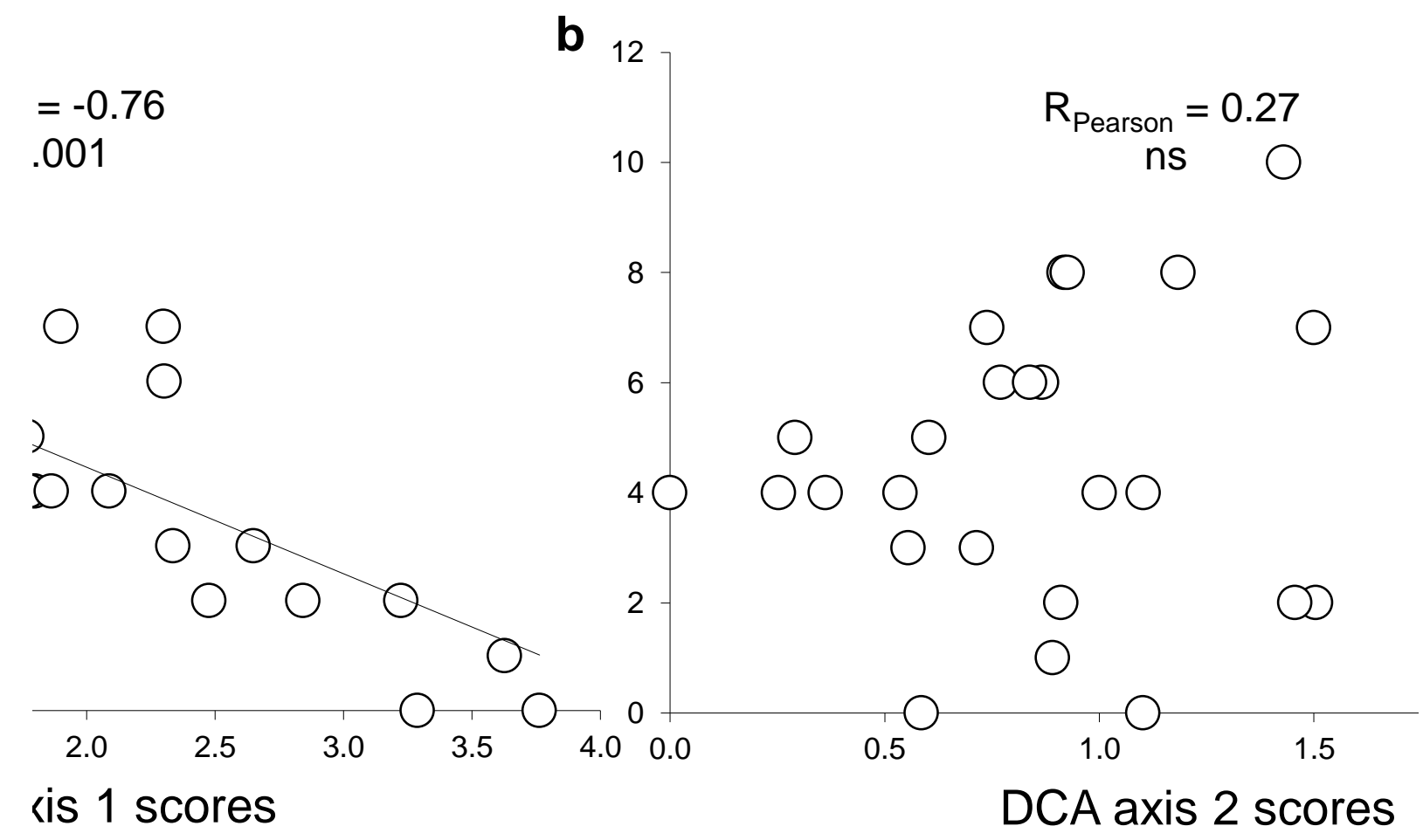




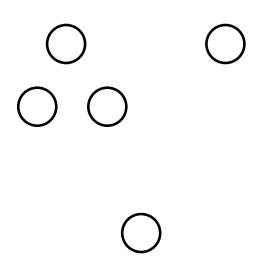

$\begin{array}{ll}2.0 & 2.5\end{array}$ 
1 Table 1 Characteristics of the six selected fires in Scots pine forests

\begin{tabular}{|c|c|c|c|c|c|c|c|}
\hline Year & Municipality & Site & $\begin{array}{l}\text { Years } \\
\text { since } \\
\text { fire }\end{array}$ & $\begin{array}{l}\text { Latitude Longitude } \\
\text { (WGS84) }\end{array}$ & $\begin{array}{c}\text { Area burned by } \\
\text { crown fire } \\
\text { [ha] }\end{array}$ & $\begin{array}{c}\text { Elevation range } \\
\text { of crown fire } \\
\text { [m a.s.l.] }\end{array}$ & Aspect \\
\hline 2006 & Verrayes & Menfrey & 4 & $45^{\circ} 46^{\prime} 00^{\prime \prime} \mathrm{N} 7{ }^{\circ} 30^{\prime} 50^{\prime \prime} \mathrm{E}$ & 4.6 & $1020-1340$ & SE \\
\hline 2005 & Verrayes & Hers & 5 & $45^{\circ} 46^{\prime} 10^{\prime \prime} \mathrm{N} 7{ }^{\circ} 29^{\prime} 54 " \mathrm{E}$ & 167.9 & $1305-1890$ & $S$ \\
\hline 2003 & St. Denis & Vorpeillere & 7 & $45^{\circ} 45^{\prime} 40^{\prime \prime} \mathrm{N} 7{ }^{\circ} 35^{\prime} 06^{\prime \prime} \mathrm{E}$ & 46.4 & $970-1525$ & SE \\
\hline 1995 & Verrayes & Del & 15 & $45^{\circ} 46^{\prime} 19^{\prime \prime} \mathrm{N} 7{ }^{\circ} 33^{\prime} 15^{\prime \prime E}$ & 22 & $1160-1460$ & $S$ \\
\hline 1975 & Verrayes & Chialey & 35 & $45^{\circ} 46^{\prime} 16^{\prime \prime} \mathrm{N} 7{ }^{\circ} 32^{\prime} 366^{\prime \prime} \mathrm{E}$ & 2.1 & $1245-1335$ & $S$ \\
\hline 1962 & St.Denis & Lavasè & 48 & $45^{\circ} 45^{\prime} 54^{\prime \prime N} 7^{\circ} 34^{\prime} 57^{\prime \prime E}$ & 5.4 & $1490-1550$ & SW \\
\hline
\end{tabular}

2 
1 Table 2 Differences in stand structural variables (mean, $\mathrm{SE}=$ standard error) among fire treatments (ANOVA F-test). Sites 2 with no letters in common were significantly different (REGWQ post-hoc test, $p \leq 0.05$ )

\begin{tabular}{|c|c|c|c|c|c|c|c|c|c|}
\hline \multirow{3}{*}{ Structural variables } & \multicolumn{2}{|l|}{ Site } & \multirow{2}{*}{$\begin{array}{c}\text { Menfrey } \\
4\end{array}$} & \multirow{2}{*}{$\begin{array}{c}\text { Bourra } \\
5\end{array}$} & \multirow{2}{*}{$\begin{array}{c}\text { Vorpeillere } \\
7\end{array}$} & \multirow{2}{*}{$\begin{array}{c}\text { Del } \\
15\end{array}$} & \multirow{2}{*}{$\begin{array}{c}\text { Chialey } \\
35\end{array}$} & \multirow{2}{*}{$\begin{array}{c}\text { Lavasè } \\
48\end{array}$} & \multirow[b]{3}{*}{ SE } \\
\hline & \multicolumn{2}{|c|}{ Years since fire } & & & & & & & \\
\hline & $\mathrm{F}$ & Sig. & mean & mean & mean & mean & mean & mean & \\
\hline \multicolumn{10}{|l|}{ Woody species regeneration } \\
\hline Total density ( $\mathrm{n}$. individuals ha ${ }^{-1}$ ) & 5.2 & 0.002 & $2420 a b$ & $1095 a$ & $3215 a b$ & $5509 \mathrm{~b}$ & $7214 b$ & $5764 \mathrm{~b}$ & 615.8 \\
\hline Total basal area $\left(\mathrm{m}^{2} \mathrm{ha}^{-1}\right)$ & 51.0 & $<0.001$ & $1.3 \mathrm{ab}$ & $0.1 \mathrm{a}$ & $3.1 \mathrm{~b}$ & $14 \mathrm{c}$ & 20.6 c & $45.6 \mathrm{~d}$ & 3.10 \\
\hline \multicolumn{10}{|l|}{ Scots pine regeneration } \\
\hline Pine density ( $\mathrm{n}$. individuals $\mathrm{ha}^{-1}$ ) & 21.6 & $<0.001$ & $0 \mathrm{a}$ & $26 \mathrm{a}$ & $331 \mathrm{a}$ & $3135 b$ & $963 a b$ & $4386 \mathrm{~b}$ & 346.4 \\
\hline Pine basal area $\left(\mathrm{m}^{2} \mathrm{ha}^{-1}\right)$ & 48.0 & $<0.001$ & $0.0 \mathrm{a}$ & $0.0 \mathrm{a}$ & $0.3 \mathrm{a}$ & $4.9 \mathrm{a}$ & $15.5 b$ & $40.7 \mathrm{c}$ & 2.90 \\
\hline \multicolumn{10}{|l|}{ Ground cover } \\
\hline Tree $\%$ cover (height $>5 \mathrm{~m}$ ) & 102.5 & $<0.001$ & $0 \mathrm{a}$ & $0 \mathrm{a}$ & $4 \mathrm{a}$ & $2 a$ & $57 \mathrm{~b}$ & $68 c$ & 5.5 \\
\hline Shrub \% cover (height $<5 \mathrm{~m}$ ) & 15.3 & $<0.001$ & $12 a b$ & $7 \mathrm{ab}$ & $41 d$ & $29 \mathrm{~cd}$ & $21 \mathrm{bc}$ & $4 \mathrm{a}$ & 2.8 \\
\hline Herbaceous $\%$ cover & 4.8 & 0.004 & $65 \mathrm{bc}$ & $55 a b$ & $64 \mathrm{bc}$ & $76 \mathrm{c}$ & $39 \mathrm{a}$ & $65 \mathrm{bc}$ & 3.0 \\
\hline
\end{tabular}


1 Table 3 Summary of univariate a and multivariate GLM b of ESM species richness (best model after stepwise selection).

2 Significant predictors $(\mathrm{p} \leq 0.05)$ in bold; df: degrees of freedom; $\mathrm{D}^{2}$ : percent deviance explained; AICC: Akaike's

3 Information Criterion with small sample correction

\begin{tabular}{|c|c|c|c|c|c|c|c|}
\hline Models/variables & Parameters & B & sig. & $\mathrm{df}$ & $\begin{array}{l}\text { Residual } \\
\text { deviance }\end{array}$ & $D^{2} \%$ & AICC \\
\hline \multicolumn{8}{|l|}{ a) Univariate models } \\
\hline \multirow[t]{2}{*}{ Time since fire (years) } & time & -0.28 & 0.009 & 28 & 38.0 & 19 & 137.6 \\
\hline & intercept & 1.53 & 0.000 & & & & \\
\hline \multirow[t]{2}{*}{ Elevation $(\mathrm{m})$} & elevation & -0.38 & 0.000 & 28 & 29.7 & 37 & 129.2 \\
\hline & intercept & 1.50 & 0.000 & & & & \\
\hline \multirow[t]{2}{*}{ Slope $\left(^{\circ}\right)$} & slope & 0.16 & 0.097 & 28 & 43.4 & 8 & 143.0 \\
\hline & (intercept) & 1.55 & 0.000 & & & & \\
\hline \multirow[t]{2}{*}{ Southness $\left({ }^{\circ}\right)$} & southness & 0.09 & 0.355 & 28 & 45.9 & 2 & 145.4 \\
\hline & (intercept) & 1.56 & 0.000 & & & & \\
\hline \multirow[t]{2}{*}{ Edge distance $(m)$} & distance & 0.04 & 0.664 & 28 & 46.8 & 1 & 146.4 \\
\hline & (intercept) & 1.56 & 0.000 & & & & \\
\hline \multirow[t]{2}{*}{ Tree density (trees ha ${ }^{-1}$ ) } & density & -0.09 & 0.406 & 28 & 46.1 & 2 & 145.7 \\
\hline & (intercept) & 1.56 & 0.000 & & & & \\
\hline \multirow[t]{2}{*}{ Tree basal area $\left(\mathrm{m}^{2} \mathrm{ha}^{-1}\right)$} & basal area & -0.34 & 0.002 & 28 & 35.0 & 26 & 134.6 \\
\hline & (intercept) & 1.51 & 0.000 & & & & \\
\hline \multirow[t]{2}{*}{ Tree cover $(\%)$} & tree & -0.24 & 0.027 & 28 & 40.3 & 14 & 139.4 \\
\hline & (intercept) & 1.54 & 0.000 & & & & \\
\hline \multirow[t]{2}{*}{ Shrub cover (\%) } & shrub & 0.10 & 0.294 & 28 & 45.6 & 3 & 145.2 \\
\hline & (intercept) & 1.56 & 0.000 & & & & \\
\hline \multirow[t]{2}{*}{ Herbaceous cover (\%) } & herbaceous & 0.04 & 0.693 & 28 & 46.8 & 0 & 146.4 \\
\hline & (intercept) & 1.56 & 0.000 & & & & \\
\hline \multirow[t]{2}{*}{ Bare soil (\%) } & bare soil & -0.03 & 0.803 & 28 & 46.9 & 0 & 146.5 \\
\hline & (intercept) & 1.56 & 0.000 & & & & \\
\hline \multirow[t]{2}{*}{ Rocks (\%) } & rocks & -0.03 & 0.784 & 28 & 46.9 & 0 & 146.5 \\
\hline & (intercept) & 1.56 & 0.000 & & & & \\
\hline \multirow[t]{2}{*}{ Light (L) } & $\mathbf{L}$ & 0.50 & 0.000 & 28 & 22.7 & 52 & 122.2 \\
\hline & (intercept) & 1.46 & 0.000 & & & & \\
\hline \multirow[t]{2}{*}{ Nitrogen $(\mathrm{N})$} & $\mathrm{N}$ & 0.07 & 0.786 & 28 & 46.9 & 0 & 146.5 \\
\hline & (intercept) & 259.08 & 0.000 & & & & \\
\hline \multirow[t]{2}{*}{ Moisture (F) } & $\mathbf{F}$ & -0.32 & 0.000 & 28 & 32.3 & 31 & 131.9 \\
\hline & (intercept) & 1.51 & 0.000 & & & & \\
\hline \multicolumn{8}{|l|}{ b) Multivariate model } \\
\hline \multirow[t]{3}{*}{ All variables included } & $\mathbf{L}$ & 0.39 & 0.000 & 27 & 20.0 & 58 & 122.1 \\
\hline & Elevation & -0.18 & 0.042 & & & & \\
\hline & (intercept) & 1.45 & 0.000 & & & & \\
\hline
\end{tabular}


Appendix 1
Click here to download Supplementary Material: ESM_1.xls

Appendix 1
Click here to download Supplementary Material: ESM_1.xls (n)

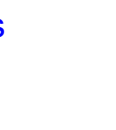

